\title{
Alexandre Leone.
}

\section{Resumo}

Este artigo enfoca a concepção de infinito atual do filósofo judeu medieval Hasdai Crescas (1340-1411), formuladas no livro Or Hashem (1410) às três primeiras proposições de Maimônides, tal como são enunciadas na segunda parte do Guia dos Perplexos. As teses de Maimônides têm como objetivo negar a possibilidade do infinito atual como magnitude imaterial ou material, como conjunto infinito de seres finitos e como série infinita de causa e efeito. Após uma breve exposição da trajetória dos conceitos de infinito nas diversas tradições sapienciais judaicas recebidas na Idade Média, indicamos como a argumentação em prol da ideia de infinito atual em Crescas dialoga com elas. Desse diálogo, emerge o conceito de infinito como singularidade atualizada paralelamente no real como vácuo infinito, lugar de coexistência de infinitos universos, e como infinito atual divino como Kavod, Glória, que preenche o universo infinito e como causa imanente da série infinita de causa e efeito que constitui a existência eterna dos seres contingentes. Na crítica à terceira proposição maimonidiana, a causa primeira é descrita como causa ontológica e imanente da série infinita de causas e efeitos. Nessa discussão, Crescas aponta para uma ideia de Deus muito diferente daquela elaborada por Maimônides. Temos aqui o debate judaico medieval entre os defensores da transcendência divina e os defensores da imanência. Esse tema é importante para a compreensão da recepção da obra de Hasdai Crescas por Picco Della Mirandolla, Bruno e Espinosa.

\section{Palavras-chave}

Crescas; Maimônides; infinito; vácuo; primeira causa

\section{Actual Infinity in Or Hashem by Hasdai Crescas (1340-1411)}

\begin{abstract}
This article focuses on the concept of the "infinite in act" of the medieval Jewish philosopher Has-dai Crescas (1340-1411), formulated in the book Or Hashem (1410) to Maimonides' first
\end{abstract}


three propositions, as set out in the second part of the Guide of the Perplexed. Maimonides' theses aim to deny the possibility of the current infinite as an immaterial or material magnitude, as an infinite set of finite beings and as an infinite series of cause and effect. After a brief exposition of the trajectory of the concepts of infinity in the different Jewish wisdom traditions received in the Middle Ages, we indicate how the argument for the current idea of infinity in Crescas dialogues with them. From this dialogue, the concept of the infinite emerges as a singularity updated parallel to the real as an infinite vacuum, a place of coexistence of infinite universes, and as an actual divine infinite like Kavod, Glory, which fills the infinite universe and as an immanent cause of the infinite series of cause and effect that constitutes the eternal existence of contingent beings. In the critique of the third Maimonidian proposition, the first cause is described as an ontological and immanent cause of the infinite series of causes and effects. In this discussion, Crescas points to an idea of God very different from that developed by Maimonides. Here we have the medieval Jewish debate between defenders of divine transcendence and defenders of immanence. This theme is important for the understanding of the reception of Hasdai Crescas' work by Picco Della Mirandolla, Bruno and Espinosa.

\section{Keywords}

Crescas; Maimonides; infinite; vacuum; first cause 


\section{Introdução}

A possibilidade do infinito existir como atualidade real no mundo é completamente negada pelo pensamento aristotélico. Segundo aquele paradigma, o infinito poderia existir apenas como potencialidade jamais realizável em ato. Somente em alguns aspectos da natureza poderia existir o infinito potencial, jamais plenamente realizado, como, por exemplo, na duração temporal, ligada à ideia da eternidade do movimento, ou na divisibilidade da matéria, tida como continua e não formada por átomos. $\mathrm{O}$ cosmos aristotélico é assim pensado como finito em seu tamanho e extensão, porém, potencialmente eterno em sua duração. No final da Antiguidade e durante a Idade Média, o cosmos aristotélico foi identificado com o mundo ptolomaico, concebido como formado por esferas celestes concêntricas, que como as camadas de uma cebola envolveriam a esfera da Terra em seu centro.

A ideia da finitude da extensão do mundo, concebido como fechado em si mesmo tornou-se predominante entre os medievais, islâmicos, judeus e latinos. O debate em geral se deu acerca de se o mundo seria finito ou eterno no tempo. Entre os pensadores islâmicos, os teólogos partidários do kalam defendiam que o mundo teria um começo temporal, tendo sido criado por Deus em um momento específico. Por outro lado, filósofos vinculados à tradição aristotélica, como Ibn Sina ou Ibn Rushd, advogavam em prol da eternidade do mundo concebido como emanado desde sempre de Deus, de quem seria ontologicamente dependente para existir. Esse debate acerca da eternidade ou da finitude temporal do mundo também foi travado nos meios judaicos e também entre os pensadores cristão latinos medievais.

Entre os judeus, Maimonides, apesar de ser, em geral, um defensor do sistema aristotélico, argumentou em prol da ideia de um mundo finito tanto na sua extensão quanto na sua temporalidade. Segundo Maimonides, o mundo teria um começo, que seria também o começo absoluto do tempo, pois, seguindo a definição aristotélica do tempo como epifenômeno do movimento e da mudança dos corpos, ele argumenta que, antes da criação do mundo material, não existindo corpos, não poderia haver temporalidade anterior ao começo do mundo. ${ }^{1}$ Essa tese buscava harmonizar a afirmação da tradição de um mundo criando por Deus com as ideias aristotélicas acerca da natureza. Como consequência lógica, Deus é concebido como absolutamente transcendente para além da extensão e do tempo, pelo autor do Mishné Torá e do Guia do Perplexos.

Nos séculos que se seguiram à publicação da obra maimonidiana, a filosofia judaica foi amplamente hegemonizada pelo aristotelismo. Entre os filósofos judeus que viveram entre os séculos XIII e XV, o debate girou em torno das distinções entre um aristotelismo neoplatonizado protagonizado por Ibn Sina (Avicena) e Maimonides e a leitura de Aristóteles proposta por Ibn Rushd (Averróis) e Gersonides. Contudo, mesmo com diferenças sobre como harmonizar Aristóteles com a tradição rabínica, em geral, a maioria dos filósofos judeus medievais pós maimonidianos concordava com a noção da transcendência divina pensada como contraponto à finitude do mundo material.

A narrativa filosófica, que buscou harmonizar a tradição judaica com o aristotelismo, teve, contudo, uma importante rival na narrativa elaborada, nesse mesmo período, nos cír-

\footnotetext{
${ }^{1}$ Moshé Maimonides, Moré Nevikhim - O Guia dos Perplexos (Jerusalém: Mossad Harav Kook, 1977), 209.
} 
culos místicos. ${ }^{2}$ Nesses círculos estavam a compor uma nova teosofia judaica, que, a partir do século XIII, começou a ser conhecida como cabala (kabalá). A literatura escrita pelos cabalistas, assim como aquela compilada pelos místicos conhecidos como hassidei ashkenaz, tinha então seu foco central o estudo do Sefer Yetzirá, obra oriunda do esoterismo rabínico do período talmúdico e comentada por diversos eruditos durante a Idade Média. Nos textos místicos judaicos medievais, a ideia de infinito é conjugada a uma noção mais dialética da relação entre imanência e transcendência divina. O Deus dos cabalistas em geral não é concebido apenas como o absoluto transcendente, sem nenhum resquício de imanência, tal como na elaboração de Maimonides. Pelo contrário, nos círculos místicos a imanência divina foi elaborada como Kavod e Shekhiná, termos alusivos à presença divina no mundo. ${ }^{3}$

É nesse contexto que Or Hashem (Luz do Nome Divino), escrito por Hasdai Crescas, publicado em 1410, aparece como uma obra sui generis, pois, contra o aristotelismo, assume a defesa da possibilidade de existir o infinito como atualidade na realidade criada. Seu autor é o rabino e filósofo judeu catalão Hasdai Crescas (1340 - 1411), que expressamente escreve Or Hashem para criticar as teses de Maimonides, Gersonides e dos aristotélicos de seu tempo. Crescas parte da crítica à interdição aristotélica à existência do infinito como atualidade, para em seguida propor a infinitude do universo, tanto na extensão quanto no tempo. Isso o leva, no final da Idade Média, a propor não apenas uma nova visão do universo, que rompe os limites nos quais ele era concebido pelos aristotélicos. ${ }^{4}$ Paralelamente, ele propõe uma nova metafísica, na qual Deus, concebido como ser necessário com infinitos atributos, não é apenas transcendente, mas também imanente ao universo infinito. As concepções de Crescas acerca da possibilidade do infinito atual encontraram pouca aceitação nos meios filosóficos de seu tempo e só foram retomadas séculos depois por Giordano Bruno, Espinosa, Joseph Raphson e Isaac Newton.

\section{A Negação Infinito Atual em Maimônides}

O primeiro dos quatro tratados que compõe Or Ha-Shem é aquele em que Crescas faz sua crítica aos fundamentos físicos e metafísicos do aristotelismo na forma de réplica às "vinte e seis proposições dos peripatéticos", elaboradas por Maimônides e pelo aristotelismo judaico anterior a ele para demonstrar a existência, unicidade e incorporeidade de Deus. Maimônides concorda com 25 das 26 proposições aristotélicas, discordando apenas da última delas. Ele então usa as proposições, avant la lettre, more geométrico, para provar a existência do Matzui Rishon, sua ideia de Deus como o ser primeiro e necessário aviceneano pensado como reunião do Primeiro Motor aristotélico com o Um neoplatônico, concebido como absolutamente transcendente ao mundo finito da cosmologia medieval aristotélicoptolomaica. Crescas critica e discorda da maioria das proposições, mas será justamente sobre as três primeiras proposições que resumem a posição aristotélica de negação da possibilidade da existência do infinito em ato que ele se deterá com maior profundidade.

\footnotetext{
2 Frederek Musall, Herausgeforderte Identiät: Kontextwechsel am Beispiel Von Moses Maimonides und Hasdai Crescas, Schiften der Horshule fur Judishe Studen Heidelbarg, (tese de doutorado, Universitat Heidelbertg, 2008 ), 132.

${ }^{3}$ Gershon Scholem, Cabala. Col. Judaica, vol. 9 (Rio de Janeiro: A. Koogan Editor, 1989), 130 -132.

${ }^{4}$ Harry Austryn Wolfson, Crescas'Critique of Aristotle (Cambridge: Harvard University Press, 1929), $114-126$.
} 
As três primeiras proposições são as seguintes:

ההקדמה הראשונה שמציאות בעל שעור אחד אין תכלית לו שקר:

Primeira proposição: A existência de uma magnitude infinita é impossível.

השנית שמציאות בעלי שיעור אין תכלית למספרם שקר, והוא שיהיו נמצאים יחד:

Segunda proposição: A coexistência de um número infinito de magnitudes finitas é impossível.

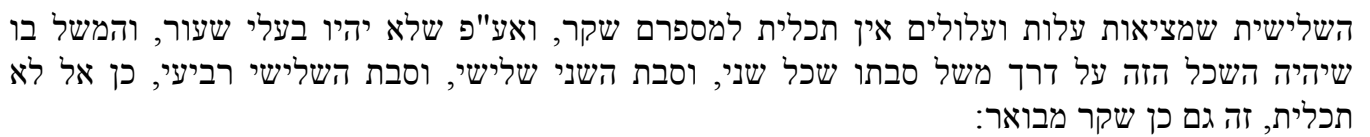

Terceira proposição: A existência de um número infinito de causas e efeitos é impossível, ainda que não sejam magnitudes. Se, por exemplo, uma inteligência fosse a causa de uma segunda, a segunda, a causa de uma terceira, a terceira, a causa de uma quarta, e assim por diante, as séries não poderiam continuar ad infinitum..$^{5}$

Estas três proposições sumarizam tanto o pensamento de Aristóteles, que nega a possibilidade do infinito atual expresso nos livros da Física e do Céu, quanto a tradição dos comentadores desde Alexandre de Afrodisia, passando pelos árabes Al Farabi e Avicena até Averróis, Avraham Ibn Daud e Maimônides.

Quando se observa a formulação das três primeiras proposições aristotélicas que negam a existência do infinito em ato contidas no Guia dos Perplexos, vemos que Maimônides - como é seu estilo também no Mishné Tora - deixa de lado a discussão e a argumentação, e simplesmente as enuncia sem se preocupar em demonstrá-las. Aparentemente, cada uma das 25 proposições que ele aceita é tida como já há muito estabelecida e conhecida e, portanto, sem necessidade de ser novamente provada. Ele discute somente a $26^{\underline{a}}$ proposição, a que afirma a eternidade do tempo e do movimento, em virtude de que ela negaria a possibilidade da criação ex-nihilo, que, como visto antes, constitui o ponto em que Maimônides está em desacordo e em tensão com Aristóteles. No entanto, a negação do infinito atual no mundo é aceita por ele como meio para provar a existência de um Deus radicalmente transcendente que não compartilha sua substância com o mundo finito.

A ideia de infinito em Maimônides não é carregada de uma conotação negativa como na tradição grega clássica; ela é apenas considerada como uma impossibilidade já estabelecida pela razão. A expressão hebraica usada na tradução do Guia dos Perplexos é ein takhlit, também usada nas traduções dos textos clássicos, em especial de Aristóteles e nas traduções dos filósofos árabes feitas para o hebraico. Ela é a tradução do termo árabe lâ-mutanâhi, usado por Maimônides no Guia dos Perplexos, originalmente escrito nesta língua. Em árabe, o termo infinito se traduz por lâ-mutanâhi, constituído da negativa la (não) e da variante $m u$ tanahi, que significa "limite, extremo, término". Da mesma forma, nos textos de Al-Kindi

\footnotetext{
${ }^{5}$ Moshé Maimonides, 159.
} 
(Filosofia Primeira) e Ibn Sina (O Livro da Alma), o termo que aparece é lâ-mutanâhi. No capítulo I de Filosofia Primeira, de Al-Kindi, quando aparece infinito, é la-mutanahi e, quando aparece eterno, é azalyi. Ibn Sina define o nihâya (limite) como "aquilo que a coisa, quantitativamente, atinge; o lugar que ela não pode ultrapassar" (Hudud, 92). Assim, quando o nihâya está precedido da negação la (não), torna-se o sem-limite, o ilimitado. No Livro da Alma, Ibn Sina também usa a expressão ghayr-mutanâhi, ou seja, in-finito. De todo modo, o mais comum é lâ-mutanãhi. O termo usado nas traduções hebraicas biti baal takhlit é um decalque do termo árabe, pois ambos se referem ao infinito como sendo literalmente o sem limite.

Entre os filósofos judeus medievais, como Saadia Gaon, Maimônides, e os averroístas Gersonides e Narboni, negam a possibilidade do infinito atual. É importante notar que o pensamento judaico tradicional bíblico e talmúdico não apenas não nega o infinito atual como também não lhe outorga um sentido negativo, como entre os gregos antigos. Porém, antes de passarmos a uma breve introdução à história da trajetória da ideia de infinito nas fontes judaicas, faz-se necessária uma breve explanação sobre as fontes gregas que tratam sobre o infinito e que ecoaram pela filosofia judaica medieval.

\section{Conceitos de Infinito na Filosofia Grega Antiga}

A história do conceito de infinito, muito embora seja um tema muito interessante, excede o escopo deste ensaio. No entanto, uma explanação breve do conceito de infinito no mundo grego antigo entre os pré-socráticos e em Aristóteles se faz necessária para um melhor entendimento do assunto tratado.

A trajetória do conceito de infinito na filosofia grega começa com a composição do termo apeíron pelos pré-socráticos. A palavra apeíron é construída a partir do termo pêras, agregado ao prefixo negativo "a". Tal palavra vem para indicar e fazer referência a algo ao qual falta determinação, ou seja, o indeterminado. $\mathrm{O}$ adjetivo apeiros indica algo que se assemelha ao caos, o caótico, ou ao qual falta sentido. A forma substantiva "to apeíron" indica a ausência de fronteira, ou a falta de definição. É interessante notar que, juntamente com a compreensão do infinito como o indeterminado, é possível derivar a palavra apeiron de outro termo, peiras (conhecimento, experiência, no lugar de pêras, limite) e, desse modo, o sentido do termo apeíron pode ser também uma alusão ao incognoscível ou ininteligível pela experiência.

A palavra apeíron aparece pela primeira vez na cosmologia grega com Anaximandro de Mileto (610-547 A.C.), discípulo de Tales de Mileto (640-545(?) a.C.). Vários pensadores da escola de Mileto tinham como preocupação fundamental determinar qual o fundamento arché da natureza (physis), isto é, o fundo inesgotável e eterno de onde vem o kósmos; e para onde regressam todas as coisas, isto é, a realidade primeira e última de tudo. Desse modo, por exemplo, para Tales, tal princípio, ou arché, seria a água, enquanto que para Anaxímenes, tal princípio seria o ar e, para Heráclito de Éfeso, o fogo. Para esses pensadores, arché era sempre concebida como um dos elementos da natureza. No entanto, para Anaximandro (610-547 a.C.), tal princípio não seria um elemento material percebido na natureza, ou uma qualidade determinada, definida ou delimitada. Segundo ele, o princípio das coisas (a arché) não seria algo visível, mas um ser etéreo e indeterminado (infinito). O apeíron (indeterminado, infinito) seria a causa e a fonte geradora dos seres, contendo em si todos os elementos 
contrários e por isso mesmo indeterminado, pois não se determinava por nenhum dos elementos contrários entre si. Esse foi um dos primeiros passos do pensamento monista entre os gregos. Para Anaximandro, apeíron não seria concebido apenas como o princípio e a causa indeterminados, mas também como algo material, e, assim entendido, ele não era apenas a causa, mas também o efeito. $O$ aperíon é então também o ariston, ou, em outras palavras, aquele ao qual embora faltem todas as características, é também o princípio no sentido da matéria à qual falta toda forma. Assim, uma das primeiras ideias do infinito no mundo grego antigo é o entendimento do apeíron como indeterminação da matéria, a falta de forma, o totalmente amorfo ${ }^{6}$, ressaltando mais as ideias de indeterminação e não clareza do que a de ilimitado. É justamente por ser entendido como aquilo ao qual falta todo conteúdo que ele é entendido como ilimitado e infinito. Alguns pesquisadores contemporâneos entendem o apeíron de Anaximandro como idêntico ao mundo, enquanto outros divergem desse entendimento. No entanto, é importante ressaltar que, dentro dessa visão monista, tal princípio não é entendido nem como transcendente, no sentido de uma substância radicalmente diferente das coisas, nem como algo desvinculado da realidade. Outros pensadores da escola de Mileto identificaram os elementos perceptíveis como o fundamento da natureza (phisis), isto é, o fundo inesgotável e eterno de onde vem o kósmos - e para onde regressam todas as coisas, a realidade primeira e última de tudo.

No entanto, é com Pitágoras e sua escola que o conceito de infinito começou a receber o sentido que teve longa trajetória nas gerações posteriores. Para os pitagóricos, a unidade é tanto a physis quanto a arché. Da distinção entre o Um limitado e o ilimitado, isto é, da distinção entre unidade e multiplicidade, derivam todos os números e suas relações aritméticas e geométricas, concebidos como os fundamentos que fixam a ordem e a harmonia no mundo. Tal ordem é considerada boa e perfeita por ser também limitada. No entanto, aquilo que é infinito e não tem limites é tido como negativo e imperfeito. Outrossim, da oposição fundamental entre limitado e ilimitado, entre unidade e multiplicidade, derivam os números que se dividem em pares e ímpares; daí, por sua vez, derivam outros pares de oposições, como ativo e passivo, macho e fêmea, movimento e repouso, bom e mau etc. O apeiron não é, assim, negado pelos pitagóricos, mas a ideia de ilimitado e indeterminado ligada a ele lhe confere nessa escola um caráter oposto à harmonia e à perfeição. Nas gerações anteriores, pêras e apeíron eram tidos como princípios igualmente materiais. No entanto, é aqui que outra mudança importante começa a ocorrer, pois um dos princípios passa a ser entendido como ligado à matéria e ao efeito, enquanto o outro se liga à forma e à causa. A partir dessa distinção, fixa-se, então, a dinâmica central da realidade. Essa distinção entre matéria e forma deixou marcas profundas no pensamento grego e, depois, no pensamento ocidental. Dessa polarização, que já se pode adjetivar de metafísica, deriva a distinção entre causa e efeito, ativo e passivo. ${ }^{7}$

Segundo Parmênides, a arché, caracterizada como o uno, imutável ou imóvel, que não tem passado ou origem nem perece no futuro, é o ser indivisível e pleno. O ser é, enquanto que o não ser não é. O ser é considerado pleno e, portanto, limitado, como a esfera que tudo envolve. O apeíron é o indeterminado, o que não pode ser pensado ou dito, estando, assim,

\footnotetext{
${ }^{6}$ Esse sentido retorna com força no neoplatonismo.

7 Sandra Valabregue-Perry, Benistar Uvniglá: Iunim Betoldot ha "Ein-sof" Bakabalá Hateosofit (Los Angeles: Cherub Press, 2010), 40.
} 
fora do $s^{8}{ }^{8}$, fora da physis. Segundo Valembregue-Perry, há até mesmo intérpretes que ligam a ideia de negação do infinito metafísico a Parmênides. Zenão, discípulo de Parmênides, nega em seus paradoxos a possibilidade da divisão infinita do movimento ou do tempo. Já outro discípulo, Melissus de Samus, chama o Um de apeíron, modificando, assim, a função do conceito de peras no pensamento de Parmênides.

A inovação conceitual de Aristóteles se dá na distinção que ele estabelece entre infinito em ato e em potência. São duas as passagens principais de sua obra, na qual o Estagirita trata do tema do infinito na Física III de 4 a 8, e em Do Céu I de 5 a 7. Na primeira passagem, também muito conhecida, ele discute as ideias sobre o infinito sustentadas por filósofos anteriores, nega a percepção do infinito metafísico e formula o tema do infinito partir de um ponto de vista físico, embora nele haja também um aspecto matemático. Sua investigação busca saber se é possível existir alguma magnitude infinita, seja ela corpórea, numérica ou cronológica Sua conclusão é a de que não pode existir um corpo infinito, pois, se existisse, o elemento, ou elementos, que o comporia terminaria por destruir os outros elementos finitos, dada sua potência infinita. Ao mesmo tempo, se existisse mais de um corpo infinito, então eles se interpenetrariam. A teoria de Anaximandro de um corpo infinito distinto dos outros elementos também é abandonada, pois ele ou seria sensível e perceptível ou seria desprovido de qualidade, o que, para Aristóteles, é um absurdo. Além disso, essa hipótese de um corpo infinito é incompatível com a noção de lugares naturais do aristotelismo. Por um lado, na passagem em Do Céu I, 5-7, Aristóteles afirma que o cosmos também não poderia ser infinito, pois, se assim o fosse, não poderia perfazer o movimento circular; mas, por outro, não poderiam existir infinitos mundos fora do cosmos, uma vez que fora do mundo não há nada, nem o pleno nem o vazio. Sua conclusão é a de que o infinito em ato não poderia existir. Entretanto, segundo Aristóteles, o infinito poderia existir em potência, não no sentido de algo em potência que poderia vir a se tornar ato, mas como algo que é sempre potencial em certos campos, sem nunca se realizar em ato. Tais campos são o do número, nos quais, dado um número, é sempre possível acrescentar-lhe uma unidade para dele obter um número maior, e ainda o da divisão de uma grandeza, por meio da qual sempre é possível obter uma grandeza ainda menor. Tal também se daria no domínio do tempo, em cujo decurso um dado momento é sempre precedido e sucedido por outro momento. Assim como entre os pitagóricos e em Parmênides, para Aristóteles, o apeiron é considerado como imperfeito e negativo.

Assim como seus contemporâneos cristãos e muçulmanos, os judeus medievais não conheceram diretamente os pré-socráticos, mas apenas indiretamente, por meio da tradição platônica e aristotélica. Oriunda não das fontes gregas clássicas, mas engendrada no ambiente cultural do helenismo tardio de Alexandria, outra tradição filosófica importante no debate medieval judaico é a do neoplatonismo, provavelmente também recebido de modo indireto por meio de fontes árabes. Em Plotino, a ideia de infinito receberá uma nova conotação. $\mathrm{O}$ Uno passa a ser concebido como infinito - não o infinito tido apenas como material dos físicos pré-socráticos, mas agora concebido como infinito imaterial caracterizado como potência produtora ilimitada e infinita. ${ }^{9}$ Se na tradição anterior o ser havia sido concebido como limitado e finito, então o Uno é pensado como estando acima do ser, ultrapassando-o.

\footnotetext{
${ }^{8}$ Marilena de Souza Chauí, Introdução à História da Filosofia Dos pré-Socráticos a Aristóteles, vol. 1 (São Paulo: Companhia das Letras, 2008), 94.

${ }_{9}^{9}$ Giovanni Reale, História da Filosofia, vol. 1 (São Paulo: Paulus, 1990), 340.
} 
Sendo infinito, o Uno só pode ser caracterizado por definições predominantemente negativas, pois as demarcações do finito não lhe cabem e, assim sendo, o Uno é também inefável. Por sua vez, do Uno procede, uma a uma, a sucessão das hipóstases. Em geral, nos escritos dessa tradição, as primeiras hipóstases são o espírito e a alma, que acabam por gerar o cosmos e a matéria. Essa última, a matéria, é também infinita e ilimitada na medida que é suscetível de receber todas as infinitas formas que procedem da atividade que do um gera o múltiplo. O infinito está, assim, nos dois extremos do um e do múltiplo como potência e como ato.

\section{Noções de Infinito no Pensamento Judaico na Antiguidade e Medievo}

Observando o percurso histórico do conceito de infinito das diferentes tendências e escolas de pensamento nas literaturas sapienciais vinculadas à tradição judaica, é possível perceber a tendência geral de identificá-lo com noções como as de inumerável, de perpetuidade e de continuidade sem fim. ${ }^{10}$ Semanticamente, a expressão ein-sof, que se tornou o termo preponderante para dizer infinito, é uma combinação bastante incomum, pois a forma negativa deveria ser lelo-sof e não ein-sof. ${ }^{11}$ No entanto, essa forma semântica não é um acidente único na língua hebraica, uma vez que, semelhante a ela, há também outros exemplos. O interessante é que, justamente, vários desses casos estão também ligados a expressões que articulam noções de infinitude.

Já no texto bíblico, é possível encontrar diversos exemplos de usos semânticos desse tipo. Nas Escrituras (Tanakh), o conceito de infinito é anunciado por meio de diversas expressões que transmitem a ideia de uma medida imensa e extremamente grande que não é possível ser contada e, até mesmo, entendida. No entanto, nem sempre elas são usadas no sentido literal, pois em muitas passagens elas têm apenas um sentido figurado, como, por exemplo, nas expressões bíblicas ein-mispar (inumerável ou sem número), ein-heker (inescrutável ou insondável) e ein ketz (sem limite ou sem fim). Em algumas passagens, tais expressões devem ser entendidas como hipérboles, mas, em outras, em especial naquelas que fazem referência a Deus, tais expressões podem ser entendidas como linguagem denotativa e conceitual. Tomemos, por exemplo, a expressão ein-mispar (inumerável ou sem número) em Gênesis 41:49, onde lemos:

\section{ויצבר יוסף בר כחול הים הרבה מאד עד כי חדל לספר כי אין מספר:}

Assim ajuntou José muitíssimo trigo, como a areia do mar, até que cessou de contar; porquanto não havia numeração [ki ein mispar].

Aqui, neste versículo, o sentido pode ser descrito como hiperbólico. O trigo que juntou José quando vice-rei do Egito era tanto que não havia como contá-lo. Não se trata, contudo, de uma quantidade infinita, mas de uma quantidade excessiva, que os seres humanos não têm meios de quantificar com precisão, dada sua imensidão. A expressão vem aqui

\footnotetext{
${ }^{10}$ Valabregue-Perry, 120.

${ }^{11}$ Ibid, 40.
} 
combinada com a alusão à areia do mar, que em outras passagens tem também um sentido similar de impossibilidade de contar. Por outro lado, em Jó 9:10, lemos:

\section{עשה גדלות עד אין חקר ונפלאות עד אין מספר:}

(Deus) O que faz coisas grandes e inescrutáveis [ad ein heker]; e maravilhas sem número [ein mispar].

Aqui, a expressão ein-mispar se refere à capacidade de Deus de produzir maravilhas na natureza, como veremos mais abaixo. Seu poder é sem número no sentido de ser incessante. Nesse versículo, o autor bíblico chega a tocar na noção de infinito, quando se refere à grandiosidade divina. A ideia de Deus ser tão grandioso que excede todo conceito aparece também na oração atribuída ao rei Salomão, narrada na passagem de I Reis 8:27, quando ele afirma que aquele majestoso templo construído durante o seu reinado não seria capaz de ser de fato uma habitação para $Y H W H$ : "Mas, na verdade, habitaria Deus na terra? Eis que os céus, e até o céu dos céus, não te poderiam conter, quanto menos esta casa que eu tenho edificado". Que a expressão ein-mispar possa ser entendida como uma alusão ao infinito quando dirigida a Deus, vemos também no Salmo 147:5:

גדול אדונינו ורב כח לתבונתו אין מספר:

Grande é o nosso Senhor, e de grande poder; o seu entendimento é infinito [einmispar].

Aqui, o autor descreve outro aspecto do poder Divino; não a capacidade de criar e fazer maravilhas ou sua imensidão que nada pode conter, mas seu entendimento, seu pensamento, é que é infinito. O ilimitado descrito pela expressão ein-mispar está longe de denotar negatividade e imperfeição. Pelo contrário. O excelso e o incontável referem-se à grandiosidade e a imponência em escala divina. É o contrário da ideia preponderante entre os gregos clássicos sobre o apeíron.

O mesmo pode ser visto em relação à expressão ein heker (inescrutável ou insondável), em Provérbios 25: 2-3:

כבד אלהים הסתר דבר וכבד מלכים חקר דבר שמים לרום וארץ לעמק ולב מלכים אין חקר:

A glória de Deus está nas coisas encobertas; mas a honra dos reis está em descobri-las. Os céus, pela altura, e a terra, pela profundidade, assim o coração dos reis é insondável [ein-heker].

A expressão ein-heker poderia ter um sentido hiperbólico, ainda que seja possível defender um sentido mais literal para a expressão nesse versículo, uma vez que o pensamento dos homens poderia ser tido como infinito. Porém, em versículos, como Isaías 40:28, lemos: 
הלוא ידעת אם לא שמעת אלהי עולם יקוק בורא קצות הארץ לא ייעף ולא ייגע אין חקר לתבונתו:

Não sabes, não ouviste que o eterno Deus, YHWH, o Criador dos confins da terra, não se cansa nem se fatiga? É inescrutável o seu entendimento [ein heker].

Ou no Salmo 145:3:

גדול יקוק ומהלל מאד ולגדלתו אין חקר:

Grande é o YHWH, e muito digno de louvor, e a sua grandeza inescrutável.

Em ambos estes versículos a expressão é associada à grandeza e ao poder divino, e possivelmente significa, no contexto, que Deus está além de todo entendimento humano. Novamente, em Jó 9: 8-10, as duas expressões ein mispar e ein heker são associadas para descreverem o poder divino em relação à grandiosidade do mundo:

נטה שמים לבדו ודורך על במתי ים: עשה עש כסיל וכימה וחדרי תמן:עשה גדלות עד אין חקר ונפלאות עד

אין מספר: נטמים

O que sozinho estende os céus, e anda sobre os altos do mar. O que fez a Ursa, o Orion, e o Sete-estrelo, e as recamaras do sul. O que faz coisas grandes e inescrutáveis [ein heker]; e maravilhas sem número [ad ein mispar].

E, finalmente, a expressão ein-ketz, sem limite ou sem fim, nos três versículo em que essa expressão aparece no texto bíblico, seu sentido é hiperbólico, como em Eclesiastes 12:12:

\section{ויתר מהמה בני הזהר עשות ספרים הרבה אין קץ ולהג הרבה יגעת בשר:}

E, demais disto, filho meu, atenta: não há limite para fazer livros, e o muito estudar é enfado da carne.

Apesar de a ideia de ilimitado e infinito no texto bíblico, ao contrário do que ocorre entre os gregos, ser associada às noções de grandeza e perfeição divinas, as expressões não fazem referência a algo que é nomeado de o ilimitado ou $o$ infinito, isto é, o termo não é um substantivo como o to apeíron grego. Deus não é chamado de o Ein-Mispar ou o Ein Ketz. As expressões são apenas adjetivos e advérbios que descrevem qualidades de coisas ou de ações, e não a própria substância infinita.

$\mathrm{Na}$ literatura dos primeiros rabinos, os tananim e amoraim, isto é, em obras como a Mishná, a Tossefta, o Talmud e as várias coleções de agadot e midrashim, compiladas entre os séculos III e VIII da Era Comum, as expressões ein ketz e ein mispar, paráfrases do infinito, aparecem em diversas passagens também, em geral, com uma função hiperbólica para fazer referência ao extremamente grande ou abundante. Aqui, não há grande inovação em relação à literatura bíblica que lhe precedeu. Contudo, é na literatura rabínica em que a expressão ein-sof (infinito) aparece pela primeira vez em várias passagens da Mishná do Talmud e, prin- 
cipalmente, do Midrash Rabá. ${ }^{12}$ Nessas passagens, a expressão também tem, como em outras expressões, um sentido hiperbólico.

É na literatura esotérica desse período, em especial no Sefer Yetzirá (Livro da Criação), que, segundo Scholem ${ }^{13}$, foi compilado em algum momento entre os séculos III e VI, em que a noção de infinito ligado a Deus assumirá um sentido mais próprio, com repercussões profundas no período medieval. Em outro livro, o Shiur Komá (Dimensões Divinas), uma espécie de antecessor do Yetzirá, que trata das dimensões do corpo divino, apesar de não usar diretamente nenhuma expressão que remeta à ideia do infinito, faz referência a medidas tão imensas que tocam em grandezas para além da percepção. Por exemplo, segundo esse livro, o corpo divino seria 180 bilhões de vezes maior do que o Universo. Estudiosos contemporâneos, como Joseph Dan, veem na linguagem desse livro, tão problemático pelo seu aparente antropomorfismo, uma tentativa de superá-lo pela via da hipérbole que rompe os limites da imaginação. ${ }^{14}$ É no primeiro capítulo do Sefer Yetzirá, no entanto, em que as noções de ilimitado e infinito relacionadas a Deus na literatura bíblica são associadas, por meio do conceito das sefirot, ao infinito presente também na criação. Na quinta mishná do primeiro capítulo, lemos:

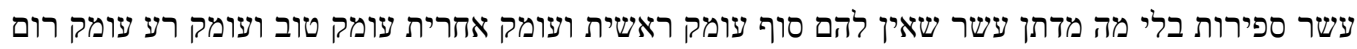

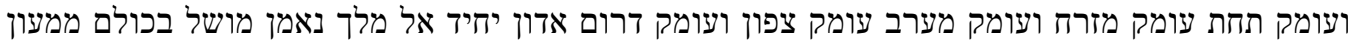

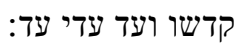

Dez Sefirot do nada. Sua medida é dez que não tem fim [sein lahem sof]. A profundidade do princípio, a profundidade do fim, a profundidade do bem, a profundidade do mal, a profundidade do acima, a profundidade do abaixo, a profundidade do leste, a profundidade do oeste, a profundidade do norte, a profundidade do sul. O Mestre único Deus fiel domina sobre todas elas desde sua Santa morada até a eternidade das eternidades.

E na sexta mishná do mesmo capítulo lemos:

עשר ספירות בלי מה צפייתן כמראה הבזק ותכליתן אין להן קץ ודברו בהן ברצוא ושוב ולמאמרו כסופה ירדופו ולפני כסאו הם משתחוים:

Dez Sefirot do nada. Sua visão é como a aparição do relâmpago. Seu limite não tem fim [ein lahem ketz]. Sua palavra nelas está correndo e voltando. Precipitamse a seu dito como um furacão. E diante de Seu trono elas se prostram.

\footnotetext{
12 Por exemplo, na Mishná Yevamot 16:4, lemos:

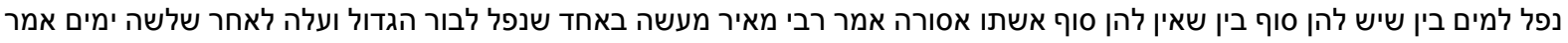

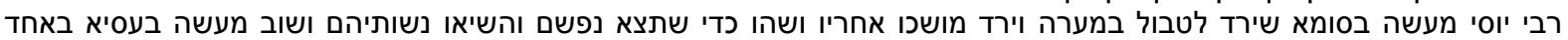
13 Scholem, Cabala, 11. ששלשלוהו לים ולא עלה בידם אלא רגלו אמרו חכמים מן הארכובה ולמעלה תנשא מן הארכובה ולמטה לא תנשא:

${ }^{14}$ Joseph Dan, "The Concept of Knowledge in Shiur Komah," Studies in Jewish Mysticism and Intellectual History Presented to Alexander Altman, edit. Siegfried Stein e Raphael Loewe (Londres: University of Alabama Press, 1979), $67-73$.
} 
As sefirot que estão ligadas à ação divina de criar e formar o mundo são retratadas como sendo infinitas. Notemos que não é apenas Deus que é predicado como infinito, mas também sua ação no mundo é infinita. É a partir dos comentários medievais ao Yetzirá que a noção de infinito se torna parte da tradição mística judaica. Nesse percurso, a noção de infinito, de adjetivo e advérbio, será transformada em substantivo, e a influência do neoplatonismo judaico será determinante.

Vários filósofos medievais judeus vinculados à tradição neoplatônica, como Ibn Gabirol, Yehudá Halevi e Bahia Ibn Pakuda, fizeram uso do conceito de infinito em referência a Deus em seus escritos. Bahia Ibn Pakuda, em seu livro Hovot Há-Levavot (Os Deveres do Coração), por exemplo, escreve sobre Deus, afirmando:

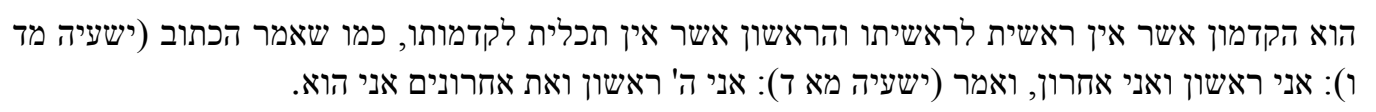

Que Ele é o primeiro cujo princípio não tem começo o princípio infinito (ilimitado) [ein takhlit]. Assim como está escrito: Eu sou o primeiro, e eu sou o último (Isaias 44:6). E também está escrito: Eu YHWH, o primeiro, e com os últimos eu mesmo (Isaias 41:4). ${ }^{15}$

Segundo Bahia Ibn Pakuda, Deus é descrito na primeira parte de Os Deveres do Coração como unidade simples, absoluta e infinita que cria o mundo em um modelo muito próximo daquele descrito por Plotino. Há trechos de seu livro, como, por exemplo, o diálogo entre o intelecto e a alma, muito similares, na estrutura, ao diálogo mais antigo entre o intelecto e a alma encontrado em Tratados das Eneadas. ${ }^{16} \mathrm{O}$ interessante é que, aparentemente, Bahia não leu Plotino diretamente, mas somente por meio da transmissão indireta vinda dos árabes.

É, no entanto, Ibn Gabirol, em um poema de forte pendor místico intitulado Shokhen Ad (O que mora nas alturas), em uma estrofe do primeiro capítulo do Yetzirá que faz referência às Sefirot, quem primeiro parece usar a expressão ein-sof como um substantivo. ${ }^{17}$ Essa passagem da expressão ein-sof de shem toar (qualificativo, adjetivo ou advérbio) para shem etzem (substantivo, nome) significa uma profunda mudança na noção de infinito que até então é encontrada na tradição judaica. Até esse momento, nas diversas literaturas judaicas bíblica, rabínica e mística, a expressão é usada em construções como ad ein-sof ou lê-ein-sof, mas nunca como no poema de Gabirol, ba-ein-sof, que já denota substantivação. Um dos primeiros pesquisadores a notar essa mudança no uso da expressão feita pelos medievais foi Scholem ${ }^{18}$, segundo o qual essa mudança tem enormes repercussões filosóficas e teológicas com relação ao conceito de infinito nas tradições sapienciais judaicas a partir de então. Uma coisa é afirmar que o poder, a grandeza ou o conhecimento de Deus é infinito; outra, bastante diferente, é afirmar que Deus mesmo é o infinito. A divindade não é apenas predicada como sendo infinita, ela é chamada de o Infinito - Ha-Ein-Sof. Essa mudança na concepção de

\footnotetext{
${ }^{15}$ Bahya Ibn Pakudá, Hovot Há-Levavot (Jerusalém: Há-Otzar: Há-Otzar Sefarim Há-Yehudi Versão 16, DBS, 2011), sp.

${ }^{16}$ Alexandre G. Leone, "The Neo-Platonic Influence in the Duties of the Heart," Vértices 8 (2006): 27 - 38.

17 Valabregue-Perry, 122.

${ }^{18}$ Ibid, 126.
} 
infinito remete aos pré-socráticos na filosofia clássica grega e à ideia de apeíron de Anaximandro de Mileto, segundo o qual o princípio das coisas (a arché) não era algo visível, mas um ser etéreo e indeterminado (infinito). O apeíron (indeterminado, infinito) seria a fonte geradora dos seres, contendo em si todos os elementos contrários e, por isso mesmo, indeterminada. Ao mesmo tempo, essa mudança remete também à ideia de Plotino do Um como Infinito, do qual emana a multiplicidade dos seres finitos. Certamente a relação na filosofia judaica medieval e na cabala é mais forte com o neoplatonismo. Todavia, em muitos escritos místicos, a tendência panenteísta irá muito além do neoplatonismo.

A substantivação da expressão ein sof transformada em um nome para designar Deus será definitivamente disseminada no pensamento judaico medieval entre o final do século XII e o início do século XIII, pelo novo misticismo que veio a ser conhecido posteriormente como a cabala (kabalá). Esse uso da expressão pode ser percebido já nos escritos de Isaac, o Cego, originário da Provença, que constituiu em volta de si, com seus discípulos, o círculo de Gerona, quando se mudou para a Catalunha. Entre os seus discípulos, destaca-se Azriel de Gerona e, na geração seguinte, seu aluno, Moises ben Nakhman, Nakhmanides. No caso de Azriel de Girona, é bastante estabelecida a influência neoplatônica em seu pensamento. ${ }^{19}$ De certo modo, pode-se entender o misticismo judaico produzido no círculo de Gerona entre os séculos XII e XIII como uma nova interpretação do Yetzirá à luz do Bahir, mesclado com ideias de matriz neoplatônica, que são fruto da recepção nos círculos místicos dos escritos dos filósofos judeus dos séculos precedentes. A substantivação da expressão Ein-Sof transformada em designação para Deus é também um dos temas centrais do Zohar, compilado no final do século XIII por Moisés de Leon. É importante notar, de modo mais preciso, que o termo Ein-Sof não é considerado pelos cabalistas medievais como um novo nome para Deus, pois, seguindo a ideia contida no primeiro capítulo do Yetzirá que relaciona dez nomes divinos às dez Sefirot, os nomes divinos seriam designações para a ação divina ou para suas emanações (atzilut). O Ein-Sof, por outro lado, é uma designação para se referir ao Deus não revelado anterior à criação e aos nomes e, desse modo, anterior mesmo ao Tetragrama. No entanto, naquele momento, isso era apenas uma das tendências da nascente cabala medieval, não sendo característica de todas as escolas, como Yossef Gikatila, por exemplo, no Guinat $E g o ́ z^{20}$ não demonstra conhecer tal designação para Deus e, assim, volta-se para uma mística do nome divino. Todavia, a ideia do Ein-Sof como anterior à emanação e, até mesmo, ao Tetragrama foi uma tendência bastante difundida e presente em Gerona, de onde se originou Rav Nissin, de quem Crescas foi discípulo.

Em seu sistema - exposto em escritos como seu comentário ao Yetzirá e em Portal do Questionador ${ }^{21}$-, Azriel de Gerona elabora um sistema no qual, do Infinito (Ein-Sof), são emanadas as Sefirot. Segundo suas palavras, o Infinito, profundo, desco Snhecido e insondável, é a causa primeira da qual emanam as sefirot e, por meio delas, ele gera todos os seres em um processo que começa a partir dessa emanação. ${ }^{22}$ Há diferenças entre os mekubalim medievais com relação a se a primeira sefirá, Keter (Coroa), identificada com a vontade divina, está ligada com o Infinito mais diretamente do que as outras sefirot. Alguns escritos e autores apontam para um lado, enquanto outros apontam para o outro, sendo que há vários

\footnotetext{
${ }^{19}$ Scholem, Cabala, 356.

${ }^{20}$ Yossef Gikatila, Guinat Egos (Jerusalém: Yeshivat Há-Haiim VeHaShalom, 2011), 11.

${ }^{21}$ Azriel de Gerona, Cuatro Textos Cabalísticos (Barcelona: Riopiedras Ediciones, 1994), 73.

${ }^{22}$ Eric Smilevitch, "Prefácio e notas," in Hasdai Crescas, Lumière de D’Eternel (Paris: Éditions Herman, 2010$), 158$ 159.
} 
em que é possível notar uma tensão neste tema. O Ein-Sof é caracterizado como desprovido de toda forma e, assim, as Sefirot são as primeiras formas ainda ligadas ao divino que emanam em uma procissão, desde a primeira delas, a Vontade, como a única que emana diretamente do Infinito. Mesmo depois de tudo ter sido gerado, o Infinito permanece idêntico a si mesmo. Sendo ilimitado, nada existe fora dele, mas como ele é o princípio além de todo movimento ou forma, ele também é transcendente a todo o campo do ser. Essa teologia que afirma o paradoxo da transcendência e da imanência em Deus é uma característica de vários sistemas místicos judaicos, mas, nos escritos de Azriel, ela transparece de modo bastante vigoroso. Com relação à criação do Universo, o Ein-Sof, por estar para além do número, não o gera diretamente. É somente com a emanação das sefirot, cuja raiz hebraica é a mesma que mispar (número), que o numerável e o dotado de forma podem surgir. Sobre isso, escreve Smilevitch: "La differánce ontologique entre l'Infini et les Sefirot repose sur l'anteriorité de Eyn-Sof et sur l'ordre de procession dês Sefirot l'une à partir de láutre. Em ce sens "l'um est le fondement du multiple". ${ }^{23}$

É interessante notar que, no mesmo período e lugar em que nos círculos cabalistas a expressão Ein-Sof era tornada substantivo e usada como uma designação para Deus, paralelamente, outras expressões hebraicas construídas em torno do termo takhlit (limite, finalidade, conclusão) começam também a ser usadas consistentemente nos círculos filosóficos para designar o infinito. A expressão ein takhlit (infinito ou ilimitado), aparentemente se torna mais comum na linguagem filosófica judaica do período que se seguiu à tradução para o hebraico do Guia dos Perplexos, de Maimônides, e dos textos de Aristóteles, de Platão e dos filósofos árabes e judeus traduzidos principalmente por Samuel Ibn Tibon, seus colaboradores e descendentes, entre o final do século XII e durante o século XIII. Outra expressão, bilti baal takhlit (literalmente aquele ou aquilo que não tem limite ou que não é limitado), dissemina-se a partir da composição do Sefer Milkhamot Ha-Shem, de Gersonides, em 1329.

A expressão ein takhlit também é usada na literatura cabalista. Por exemplo, o Zohar, composto no final do século XIII, faz uso de uma linguagem que interpola e mistura as expressões ein takhlit e ein sof. Em diversas passagens, o Zohar mistura e amalgama as duas expressões tanto em hebraico quanto em aramaico, em uma linguagem em que muitas vezes são utilizadas combinações tais como: ad ein sof ... ad ein takhlit (עד אין תכלית ...עד אין סוף), ad leit sof veleit takhlit (עד דלית סוף ולית תכלית) e ad leit sof vetakhlit (עד דלית סוף ותכלית). Ou עדית (עדיר) Seja, temos na literatura tecida à volta do Zohar um exemplo contundente de um pensamento que ao mesmo tempo relaciona as duas expressões, ein sof e ein takhlit, entendendo-as, portanto, como sinônimas. O contrário, porém, ocorre com bem menos frequência. O único filósofo aristotélico que nesse período usa a expressão ein-sof é Moises de Narboni. Na literatura filosófica escrita entre os séculos XIII e XV, a expressão ein sof para designar o infinito praticamente não é usada nem como qualificativo nem, muito menos, como substantivo. Como vimos anteriormente, a expressão ein sof, encontrada nas traduções dos escritos de Saadia Gaon e dos neoplatônicos, no vocabulário dos filósofos do período posterior a Maimônides, utilizada para infinito, passou a ser referido de forma quase técnica e consistente como ein takhlit ou bilti baal takhilit. É importante destacar que os círculos que se dedicavam à filosofia judaica no período da recepção da obra de Maimônides, entre os séculos XIII e XV, passam a estar sob a preeminência do paradigma

\footnotetext{
${ }^{23}$ Smilevitch, 162.
} 
aristotélico. Assim, as obras compostas nesse período, quando se voltam para o tema do infinito, assumem sempre o ponto de vista que nega o infinito atual. Em outras palavras, as expressões que se referem ao infinito são usadas sempre em um contexto de negação da possibilidade de sua existência atual, considerada pelos diversos filósofos como algo absurdo. Somente Crescas usará as expressões, afirmando e defendendo a possibilidade da atualidade do infinito. Porém, segundo o paradigma aristotélico defendido por Ibn Daud e Maimônides e, depois, também por Gersonides, uma magnitude infinita poderia ser, no máximo, admitida como potencial, como no caso da ideia da eternidade do tempo para Maimônides, para quem a única exceção é o número de almas que poderia ser infinito, enquanto que, em Gersonides, nem isso. Para eles, essa seria a única possibilidade da divisão potencialmente infinita da matéria. Além desses casos, o infinito estaria fora da existência (metziut) dos seres sensíveis e, para Maimônides, fora da existência mesmo dos seres inteligíveis, se eles estivessem em uma relação de causa e efeito entre si. Ao mesmo tempo, como já vimos, a expressão ein-sof, corrente na literatura kabalista, aponta, em geral, para a fonte sem fim da existência, entendida como a própria dinâmica da Presença Divina no mundo e além dele. Notemos que, para certos kabalistas, o mundo poderia ser entendido como limitado, ainda que a existência fosse entendida como infinita. Interessante que Maimônides, que nega a possibilidade do infinito atual entre os seres contingentes, jamais liga a ideia de infinito a Deus. Para ele, afirmar a unidade radical de Deus significa formular uma teologia negativa, uma vez que nenhum atributo positivo pode ser predicado a Deus sem que isso enfraqueça a ideia da divindade como unidade radical, concebido no espírito do aristotelismo neoplatonizado. Dessa forma, o tema do infinito só aparece no Guia dos Perplexos no final da primeira parte, no contexto da crítica ao kalam, e no começo da segunda parte, no contexto da formulação das vinte e seis proposições.

\section{O Vácuo como Magnitude Infinita}

A primeira parte do Primeiro Tratado de Or Hashem é dedicada à exposição exaustiva dos argumentos aristotélicos em prol das 26 proposições, inclusive as três primeiras contra o infinito, tal como explicados pelos comentaristas medievais da obra de Maimonides e Averróis, os principais oponentes com quem Crescas debate ao longo do primeiro tratado. Contudo, é somente na segunda parte do primeiro tratado de Or Hashem que Crescas passa a expor sua crítica a esses argumentos, seguindo um método dialético que parece se assentar no pilpul, isto é, na dialética talmúdica, aprendida desde sua juventude na academia de Nissin Gerondi, em Barcelona. É possível que seu método de argumentação guarde relação com a dialética escolástica medieval latina. Crescas, que por muitos anos foi rabino da corte, esteve em uma situação de maior possibilidade de contatos com autores latinos do que a maioria dos seus predecessores ou contemporâneos.

Pines foi o primeiro pesquisador a notar que o antiaristotelismo de Crescas apresenta um paralelismo notável com diversos temas e elementos encontrados em autores latinos medievais ligados à nova abordagem que se desenvolve em torno da Universidade de Paris no século XIV, em obras de pensadores como Duns Escoto, Nicolau Oresme e João Buridan. Ele chega a propor que a obra de Crescas seria uma 
espécie de escolástica judaica, algo como um paralelo da falsafa judaica produzida no mundo islâmico. Contudo, devemos ressaltar que, se há um encontro temático entre Crescas e esses autores cristãos latinos, que também criticaram de algum modo o aristotelismo e principalmente o averró́smo, contudo, é importante notar, como o faz Harvey, que as conclusões a que chega Crescas, em sua crítica ao aristotelismo, em muitos casos, são diferentes das conclusões desses mesmos escolásticos cristãos de seu tempo. Entre eles, há em comum a investigação de temas que fogem ao paradigma aristotélico, como a possibilidade do vácuo ou do infinito atual. De todo modo, vale a observação de Musall de que o pensamento formulado por Crescas é também fruto das condenações de Paris de $1277^{24}$, que, se por um lado, visaram atacar o averroísmo latino, por outro, abriram caminho para um pensamento que pôs em questão as bases do aristotelismo medieval.

Não é difícil de imaginar como esse contato com o pensamento escolástico de seu tempo teria se dado. Crescas era oriundo de rica família de eruditos, tanto no campo rabínico quanto nas ciências, sendo que um dos ramos de sua família em Palma de Mallorca era de respeitados cartógrafos que há muito serviam aos reis de Aragão. Harvey nota que esse contato poderia ter se dado ainda em Barcelona, uma vez que ficavam localizados muito próximos ao centro de estudos dos franciscanos, receptivos ao pensamento de Duns Escoto e à academia rabínica. ${ }^{25}$ Outra possibilidade de contatos pode ter se dado na corte em Saragossa, para onde Crescas se mudou quando foi apontado como juiz do supremo tribunal rabínico do reino.

Ambas as matrizes, a rabínica e a escolástica estariam presentes em seu método dialético único. Segundo esse método, primeiro é exposto o lado do oponente por meio de sua própria argumentação e de suas palavras, para depois, no exercício da crítica, formular e expressar sua posição. Seguindo esse método, ele formula seu conceito de infinito, no qual são distinguíveis elementos que nas tradições judaicas anteriores já apareceram amalgamados, com noções da escolástica antiaristotélica com que entrou em contato. Esses elementos são, porém, recontextualizados, gerando uma nova perspectiva sobre o infinito que vai além das tradições com as quais ele interagiu.

O hidush (inovação) de Crescas é o de aproximar o infinito teológico da ideia do infinito atual existente no Universo ou, como ele o denomina, a realidade ou a existência (metziut). Dito de modo sumário, seu método dialético de exposição e crítica propõe um sistema no qual o Deus, ser necessário de infinitos atributos, ao mesmo tempo (nivdal) transcendente ou incorpóreo, está imanente no Universo infinito (metziut), preenchendo toda a extensão tridimensional infinita do vácuo com sua presença (kavod), que é o Lugar do Mundo. Esse Deus é também a causa imanente de toda a série infinita de causa e efeito que gera os seres contingentes e mantém a tendência à existência que se sobrepõe à tendência oposta para o nada. Além disso, nesse sistema, o Universo infinito, fruto da criação eterna, é possivelmente composto de infinitos mundos finitos (olamot) criados em sucessão ou em paralelo.

\footnotetext{
${ }^{24}$ Musall, 135.

${ }^{25}$ Warren Zeev Harvey, Rav Hasdai Crescas. Col. Guedolei Ha-Ruakh Ve-Ha-Yetzirá Ba-Am Ha-Yehudi, (Jerusalém: Merkaz Zalman Shazar Le-Toldot Israel, 2010), 17.
} 
Assim, a ideia de infinito atual em Crescas está presente tanto em Deus, quando atualizada no Universo de vários modos. Há um paralelismo entre o infinito atual em Deus e no Universo.

A partir da crítica às três primeiras das 26 proposições aristotélicas que abrem a segunda parte do Guia, vejamos agora como Crescas chega à sua formulação de uma metafísica e uma física do infinito atual.

A crítica à primeira proposição, que afirma que "a existência de uma magnitude infinita é impossível" 26 , é feita nas quatro meditações que compõem o primeiro capítulo da segunda parte do primeiro discurso. Por meio dela, Crescas busca provar a possibilidade da existência de uma grandeza ou magnitude tanto imaterial quanto material infinita. É aqui que ele expõe seus argumentos em prol do vácuo em sua argumentação de que o vácuo infinito é o lugar universal de todos os corpos, rejeitando também desse modo o conceito aristotélico de lugar como a superfície dos outros corpos que envolvem um dado corpo. ${ }^{27}$ Através desse caminho Crescas constrói seu conceito de vácuo (reikut) e de lugar (makom), relacionando-os com o a ideia de infinito atual apresentado em Or Hashem.

O que seria essa grandeza imaterial infinita? Algo cujas partes podem ser medidas ainda que ela mesma não possa ser medida em sua totalidade em virtude de ser infinita. Segundo Crescas, essa grandeza é o próprio espaço abstrato geométrico, a extensão pura separada e distinta dos corpos que é idêntica ao vácuo (reikut). Crescas rejeita as argumentações de Aristóteles contidas em Física III, repetidas por seus comentadores medievais que negam a possibilidade do vácuo baseando-se na afirmação de que uma grandeza infinita deva ser, por definição, infinita em todas as suas partes. Eles argumentavam que, se existisse uma grandeza infinita imaterial, enquanto grandeza, ela deveria ser divisível em suas partes, e, sendo uma magnitude infinita, suas partes deveriam sê-lo também. Contudo, como a parte pode ser igual ao todo? Se ela não é divisível, não pode ser uma magnitude. Então uma grandeza imaterial infinita é um absurdo, contra argumenta Crescas, afirmando que mesmo que o todo seja infinito, não é obrigatório que suas partes também o sejam, pois o infinito não é necessariamente uma qualidade intrínseca a ela, mas unicamente uma quantidade, ou seja, um acidente. Ela não é “o infinito" em si, é apenas predicada como infinita. Tal é para Crescas o caso da extensão tridimensional pura ou o vácuo. Ele é a própria extensão imaterial. É possível medir um volume de vácuo ou a distância entre dois pontos sem que isso comprometa a infinitude da extensão tridimensional com um todo, pois ela não é material, por não ser em si mesma corpórea e pode se estender muito além dos limites do mundo fechado ptolomaico elevado à condição de paradigma pela cosmologia medieval. A extensão tridimensional é concebida como infinita em sua totalidade sem que seja infinita em sua essência, o que faria com que tivesse que ser necessariamente infinita em todas as suas partes. Segundo Crescas, essa possibilidade não chega a ser investigada em nenhum momento por Aristóteles, o que torna o argumento defectivo e falacioso.

\footnotetext{
ההקדמה הראשונה שמציאות בעל שעור אחד אין תכלית לו שקר Em hebraico está escrito

${ }^{27}$ Aristóteles, Physics. Col. Great Books of the Western World (Chicago, London, Toronto: Enciclopaedia Britannica, Inc, 1955), $289-295$.
} 
O termo hebraico usado por Crescas para dizer imaterial é nivdal - נבדל O significado comum do termo é distinto, diferente, separado ou isolado. Outra palavra da mesma raiz, nivdelut, significa isolamento. No vocabulário filosófico hebraico medieval, elaborado a partir do final do século XII, nivdal é usado para dizer transcendente, incorpóreo, ou fazer referência a uma das dez inteligências transcendentes que movem as esferas celestes. Ao pé da letra, imaterial seria ló gashmi ou incorpóreo. Nesse sentido, quando Crescas denomina a extensão tridimensional ou o vácuo de nivdal, faz referência a este como algo incorpóreo que recebe e dá suporte à forma corporal, sem que, com isso, ele se confunda com o corpo e, por isso mesmo, permanece separado e distinto do corpo, transcendendo-o. É desse modo que a extensão em si mesma, ou o espaço puro é concebido como realidade incorpórea. Esse ponto de vista distingue extensão de matéria.

As três dimensões imateriais da extensão constituem o espaço, como volume vazio (rahak nivdal). Esse volume vazio infinito é o suporte para qualquer forma corporal. Contudo, o espaço concebido como vácuo, não é um meio, como o ar ou a água e, assim, ele não auxilia nem se opõe ao movimento dos corpos. Crescas rejeita desse modo uma ideia central na física aristotélica segundo a qual o meio é necessário para o movimento, mas, prefigurando a física que se desenvolverá nos séculos seguintes, ao contrário, afirma ele, é justamente, em graus variados, o meio material que impede o movimento e não o seu suporte, como afirmam os aristotélicos. Concebido desse modo, a extensão imaterial ou o vácuo é o espaço vazio (panui) que, quando recebe um volume corporal que o ocupa, torna-se o lugar (makom) do corpo. Ele mesmo, por ser incorpóreo, não tem limites, assim nada o impediria de estender-se infinitamente em todas as direções, para fora do mundo finito da cosmologia medieval, além da esfera das estrelas fixas. Essa é a prova apresentada por Crescas para demonstrar a existência de uma grandeza imaterial infinita.

Uma primeira noção de infinito é então tentada por Crescas. Essa primeira noção é construída a partir da crítica feita à prova de Al-Tabrizi para refutar a possibilidade do infinito. Aqueles que negavam o infinito atual baseavam-se, como o fez Al-Tabrizi, no paradoxo de duas linhas infinitas, porém de tamanhos diferentes, para provar a impossibilidade do infinito atual. O paradoxo é enunciado então por dois segmentos de reta finitos de tamanhos diferentes A-B e C-D, sendo A-B maior do que C-D. Tomamos agora mais dois segmentos de reta, um que começa em $\mathrm{E}$ indo até o infinito e outro que vai de $\mathrm{F}$ até o infinito. Estes dois últimos segmentos são iguais em tamanho, ou seja, são infinitos. Se tomamos A-B mais E infinito e C-D mais F infinito, como A-B é maior do que C-D, então A infinito é maior do que $\mathrm{C}$ infinito. Desse modo, então, teríamos dois segmentos infinitos de tamanhos diferentes, só que isso é absurdo, o que provaria, segundo Al-Tabrizi, que o infinito atual é impossível. Crescas contra argumenta afirmando que não se pode acrescentar nada a um conjunto infinito de modo a se obter um infinito maior do que o primeiro com essa adição, isso porque o infinito não pode ser medido. Então não se pode dizer que um dos segmentos de reta é maior do que o outro e, portanto, é falso o raciocínio que leva a este paradoxo ${ }^{28}$. Ele está baseado em uma ilusão intelectual, ou seja, em uma falácia que toma aquilo que é finito e mensurável como analogia para daí tirar conclusões sobre o que é infinito e, portanto, imensurável. É

\footnotetext{
${ }^{28}$ Hasdai Crescas, Or Hashem, ed. Shlomo Fisher (Jerusalem: Sifrei Ramot, 1990), 65.
} 
assim então que, para Crescas, a imensurabilidade é uma característica intrínseca do infinito. O vácuo infinito é assim o espaço imensurável. Nas suas palavras em Or Hashem:

ומה שאין תכלית לו הוא בלתי משער.

E aquilo que não tem fim [she-ein takhlit lo] não é mensurável [hu bilti meshuar]. ${ }^{29}$

Essa primeira definição de Crescas faz lembrar a antiga expressão ein mispar (sem número, inumerável), usada em diversos versículos bíblicos e repetida no Talmud e no Midrash. Em geral, a expressão ein mispar se refere, no contexto das passagens em que aparece, não apenas àquilo que não se pode numerar, mas também é possível entendê-la como se referindo àquilo que é imensurável, como já visto antes. Há, no entanto, duas diferenças importantes entre a expressão mais antiga ein-mispar e a expressão $h u$ bilti meshuar, usada por Crescas nessa passagem. Em primeiro lugar, a expressão usada por Crescas é em hebraico mais precisa. Em hebraico, as palavras shiur e meshuar referem-se a noções de medida, tamanho, razão matemática, proporção e, por extensão, às ideias de sentido e lição ou aula e àquilo que é mensurável etc. Nessa raiz hebraica, a noção de infinito aparece não apenas como imensidão inumerável formada por quantidades discretas, mas também como contínuo, como no caso dos dois exemplos da linha e do tempo oferecidos, na passagem, pelo próprio Crescas. Tal como no caso da linha ou do tempo, a extensão tridimensional, o vácuo é pensado por Crescas como contínuo infinito. Ele chega muito próximo da ideia de espaço que duzentos e cinquenta anos depois será proposta por Isaac Newton, que, aliás, usa também o termo makom (lugar) em seus escritos..$^{30}$ Outra importante diferença no uso feito por Crescas em relação à expressão ein-mispar como ela é usada na literatura bíblica e rabínica é que, ao invés da expressão ser usada de modo hiperbólico quando se referindo às coisas, aqui ela é usada como linguagem denotativa e conceitual precisa. Como visto anteriormente, somente nas passagens referentes a Deus a expressão ein mispar poderia ser tida como linguagem denotativa na literatura bíblica e rabínica. Nos outros casos, em geral, ela poderia ser interpretada como figura de linguagem, dando margem ao entendimento de que a ideia de infinito atual no mundo poderia não ser corrente entre os judeus na antiguidade. Em Crescas, porém, a ideia do infinito atual nos seres, e não apenas em Deus, aparece com clareza e precisão. Nisso seu pensamento aproxima-se das ideias de dois cabalistas cujas obras eram conhecidas em Aragão, a saber, Isaac, o Cego, e Azriel de Gerona. Entre eles também o infinito é afirmado em Deus assim como no mundo. ${ }^{31}$ Diferente desses dois místicos, porém, a abordagem de Crescas se apresenta mais geométrica e física, fundada em uma argumentação que está em diálogo com a tradição filosófico-aristotélica que nos séculos preceden-

\footnotetext{
${ }^{29}$ Ibid. A tradução de Wolson para essa passagem é: “because an infinite is imensurable". Vide Wolfson, Crescas'Critique of Aristotle (Cambridge: Harvard University Press, 1929), 191.

${ }^{30}$ Brian P. Copenhaver, "Jewish Theologies of Space in Scientific Revolution: Henry More, Joseph Raphson, Isaac Newton and their Predecessors," Annals of Science 37 (1979): 489 - 548.

${ }^{31}$ Gershon Scholem, Origins of the Kabbalah (Princeton: JPS e Princeton University Press, 1990), 393, 430 - 454.
} 
tes florescera, com sua linguagem e vocabulário. Em outras palavras, diferente de Isaac, o Cego, e Azriel de Gerona, Crescas argumenta como filósofo.

Na segunda meditação, em Or Hashem (Luz do Nome Divino), na segunda parte do primeiro tratado, Crescas continua sua crítica à primeira proposição do Guia do Perplexos defendendo agora a possibilidade da existência de uma grandeza material infinita, a qual seria o corpo infinito pensado a princípio como esfera infinita, isto é, como concavidade infinita ou então como elemento infinito existente para além dos cinco elementos que compõem o mundo finito. Para defender a possibilidade da existência de tal corpo infinito, Crescas faz a crítica dos argumentos de Aristóteles contrários a tal possibilidade: a definição aristotélica de lugar, a de que o infinito é absurdo porque se assim o fosse o mundo não seria inteligível, de que a existência de um elemento infinito destruiria os demais elementos finitos, da leveza e gravidade e da noção de lugar natural. Aqui, o tema será abordado na medida que se relaciona à exposição do seu conceito de infinito. Crescas começa sua crítica a Aristóteles afirmando que a definição peripatética de lugar é falaciosa, pois apresenta como premissa aquilo que justamente carece ser provado. É um raciocínio circular, uma petição de princípio. Ao definir o lugar de um corpo como sendo a superfície ou superfícies dos outros corpos que o contém, Aristóteles já está determinando o corpo como finito. Contudo, contra-argumenta Crescas, que aquele que advoga a possibilidade da existência de um corpo infinito não definirá o conceito de lugar do mesmo modo, isto é como a superfície que o contém, pois, essa definição seria contraditória à noção de infinitude. Assim, conforme a conclusão da primeira meditação, as três dimensões da extensão formam um contínuo infinito distinto dos corpos. Desse modo, o conceito de lugar de um corpo não pode mais ser definido de modo bidimensional como área igual à sua superfície, porém, separada, e que contém o corpo. O conceito de lugar é agora definido de modo tridimensional como volume igual a corpo, porém, distinto dele de vácuo (reikut), isto é, de ou do espaço vazio (panui) que é penetrado e penetra o corpo. Esse volume é, ademais, a forma (tzurá) do corpo:

ולזה, היה האמת עד לעצמו, ומסכים מכל צד, שהמקום האמיתי הוא הפנוי.

Consequentemente, isto está de acordo com a natureza da verdade, que é evidente em si mesma que o lugar verdadeiro (dos corpos) é idêntico ao espaço vazio. $^{32}$

Essa definição tridimensional de lugar tem várias consequências com relação a outros aspectos do conceito aristotélico de lugar repensados por Crescas, como as noções de leveza e gravidade e de lugar natural, aplicadas ao corpo infinito e aos corpos em geral.

A objeção aristotélica contra a existência de um corpo infinito, segundo a qual a presença de um elemento infinito destruiria os demais, é respondida por Crescas com o argumento que esse elemento poderia ser neutro e destituído de toda qualidade (ekhut) e, assim, não apenas não promover a destruição dos outros elementos, mas, pelo fato de não ter qua-

${ }^{32}$ Crescas, 69. 
lidades, ser também o substrato ou o fundamento (yessod) dos outros. Em OH 1,2,7 esse elemento é chamado de hilui, termo hebraico emprestado do grego hilo ${ }^{33}$, isto é, a matéria primordial. Aqui, sua ideia de infinito se aproxima do apeiron, de Anaximandro de Mileto. Muito provavelmente, trata-se de uma aproximação acidental, pois Crescas só conheceu Anaximandro por meio de Aristóteles. A possibilidade do recebimento de ideias com a do ar dos estoicos é uma linha investigativa que, no entanto, não poderia ser descartada. Segundo Freundental, ideias estoicas tiveram sua recepção na tradição medieval judaica de comentário do Yetzirá, chegando até às obras escritas na França no século XIII. ${ }^{34}$

No entanto, é a crítica de Crescas à objeção aristotélica de que o infinito atual não poderia existir, pois, se assim fosse, o mundo não seria inteligível, o mais importante momento na segunda meditação para compreender sua ideia de infinito em suas relações não apenas com a tradição filosófica, mas também com as tradições sapienciais judaicas que o precederam. Sobre a ideia da inteligibilidade do mundo, Moisés Narboni, que viveu no século XIV, em seu comentário a Averróis, escreve que "a afirmação de Aristóteles segundo a qual os princípios devem ser conhecidos é baseada em sua crença que para que uma coisa seja conhecida perfeitamente é necessário conhecer suas causas e princípios". ${ }^{35}$ Sabemos que em Aristóteles um dos motivos alegados para que o número de causas seja finito é que de outra forma a relação de causa e efeito seria incompreensível, assim para ele é possível conhecer uma série infinita de causas. Do mesmo modo, o motivo aceito na tradição aristotélica judaica medieval para que o número de princípios seja finito é expresso em vários autores medievais como o de que na natureza não há nada em vão e, sendo assim, se a natureza do ser humano é imbuída do desejo de compreender todas as coisas e isso implica então em que ele tem que conhecer todas as suas causas e princípios, assim, para que a natureza humana e a natureza do mundo sejam compatíveis, o mundo deve ser inteligível e então seus princípios devem ser finitos, pois, de outra forma, o mundo não poderia ser conhecido em sua totalidade. ${ }^{36}$ Em outras palavras, o universo aristotélico é concebido como finito não apenas para ser perfeito, mas também para ser inteligível.

A resposta de Crescas a essa argumentação que aparece na Física I, 7 é surpreendentemente direta e concisa:

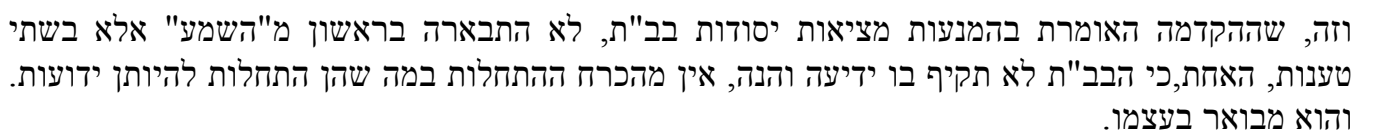

Com efeito, a premissa que estipula que um número infinito de elementos [metziut iessodot bilti baal takhlit] é impossível não é estabelecida no Primeiro Livro da Física [Hashema] a não ser em virtude de dois argumentos [taanot], sendo o primeiro aquele que afirma que a ciência, o conhecimento [iediá] não pode compreender [lo takif] o infinito. E eis que nada há na natureza dos princípios

\footnotetext{
${ }^{33}$ Warren Zeev Harvey, "Nissim of Gerona and William of Ockham on Prime Matter," in Jewish History, vol. 6 n. 1/2 The Frank Talmage memorial Volume (Jerusalem, 1992), 87 -98.

${ }^{34}$ Gad Freudenthal, "L'heritage de La physique stöicienne dans La pensée juive mediévale: Saadia Gaon, lês dévots rhénans, Sefer Há-Maskil," Revue de Metaphysique et de Morale 4 (Paris, 1998).

${ }^{35}$ Wolfson, 426.

${ }^{36} \mathrm{Ibid}, 427$. Olhar nota 44.
} 
considerados em sim mesmos que requeira que eles sejam necessariamente cognoscíveis. E isso é claro em si mesmo. ${ }^{37}$

O infinito que antes foi conceituado como o imensurável (ein shiur) é agora também concebido como aquilo que não pode ser compreendido pelo conhecimento. Notemos que sua argumentação não afirma em momento algum que todo conhecimento é impossível. Crescas não desconfia da possibilidade da obtenção de conhecimento pelos seres inteligentes finitos. O que ele afirma é que o mero fato de que o infinito não pode ser abarcado pelo conhecimento, em outras palavras, de que o universo infinito (metziut) não possa ser completamente inteligível, não é motivo suficiente para rejeitar a possibilidade do infinito atual. Para ele é justamente a premissa em que se baseia Aristóteles de que o mundo é necessariamente inteligível que carece ser provada. Sua opinião vai em sentido oposto: a existência ou realidade finita (metziut) não é completamente compreensível. Mais à frente, ao discorrer sobre os infinitos atributos de Deus, ele afirma que somente o ser necessário (haiav hametziut) pode abarcar o conhecimento do infinito. Essa noção se apresenta muito próxima daquela expressa na linguagem bíblica e repetida no hebraico mishnaico dos tananim e amoraim que fala do infinito como ein heker (inescrutável ou insondável). Mas ele não está apenas a retornar à expressão mais antiga, como já visto no caso de ein mispar (inumerável). Os textos bíblico e rabínico antigo a usavam de modo hiperbólico quando se referiam ao mundo. Crescas, no entanto, usa a mesma noção numa linguagem denotativa para falar do infinito atual no mundo. A noção de infinito contida nessas expressões é usada de outro modo. Ele recorre à tradição judaica ao mesmo tempo em que a modifica. Nesse sentido, sua abordagem do infinito se distancia da tradição filosófica de seu tempo e se apresenta como uma reaproximação das tradições sapienciais judaicas não filosóficas que foram cultivadas e transmitidas em contato, porém de modo independente, da filosofia judaica cultivada entre os séculos XII e XV. Ser o infinito conceituado como inescrutável, insondável e não necessariamente cognoscível assim como incontável e imensurável, não significa para Crescas que ele não possa ser pensado e que a razão não possa ter com ele um trato matemático e geométrico. Pensar o infinito exige, no entanto, um caminho sui generis em relação a procedimento no trato com grandezas e números finitos. Pensar o infinito a partir do finito é cair no raciocínio falacioso. O infinito deve ser pensado a partir de sua singularidade. Se assim for feito, a razão no trato com a física e a metafísica é que é levada a postular a possibilidade de sua atualidade. Crescas fundamenta filosoficamente, em oposição a Aristóteles, Maimonides, Averróis e Gersonides, uma ideia de infinito que é baseada em noções já encontradas nas tradições sapienciais judaicas, mas que antes dele não recebera a mesma lapidação filosófica. É nesse exato contexto que ele é um filósofo medieval sui generis, pois coloca em diálogo essas tradições vistas em seu tempo como antagônicas.

Um terceiro aspecto da ideia de infinito em Crescas aparece no final da segunda meditação, no que poderia ser chamado de um apêndice desta. Nesta passagem bastante densa de Or Hashem, ele se volta para o que pode ser considerado como um viés teológico de sua ideia de infinito. Aqui ele vai relacionar três ideias sobre Deus. A primeira é a de Deus ser a forma de toda a existência ou de todo o universo infinito (tzurat lê khlal há-metziut). A segunda, ligada a um nome rabínico dado a Deus, Há-Makom, o Lugar, que é explicado no Midrash Rabá 68:11 como significando que "Deus é o Lugar do mundo, mas o mundo não é o seu

\footnotetext{
${ }^{37}$ Crescas, 66.
} 
lugar". E a terceira a de que assim como as dimensões do vácuo preenchem todo o corpo, mas não se confundem com ele; da mesma forma, sua Presença, sua Glória (Kavod) preenchem todo o universo, mas não se confundem com ele. Por trás de cada uma dessas três ideias relacionadas está a sua noção própria de uma imanência divina que não se opõe completamente à noção oposta de transcendência divina. Essa posição também ocorre no pensamento de vários cabalistas medievais e pós-medievais. A ideia de Crescas da relação entre imanência e transcendência divinas se coloca bastante diferenciada da transcendência radical do Deus proposta por Maimônides. Ela também não é exatamente igual à imanência radical, que em geral é atribuída a Espinosa. Com relação à ideia de Deus em Maimônides, ela é díspar o suficiente para que na terceira parte do primeiro discurso, dedicada à formulação de suas provas para a existência, unidade e incorporeidade de Deus, fique evidente aquilo que já está óbvio desde o início do Primeiro Discurso de Luz do Nome (Or Hashem), a saber, que refutar a maioria das 26 proposições do Guia dos Perplexos é desmontar as provas de Maimônides para existência, unidade e incorporeidade de sua ideia de Deus. Dito de outro modo, seu caminho no livro o leva a refutar o Deus maimonidiano, ou seja, a dizer que o infinito atual pode ser predicado tanto a Deus, enquanto ser necessário; quanto ao universo ou a existência, enquanto conjunto dos seres contingentes. Do ponto de vista de sua noção de infinito, a ideia de que Deus preenche todo o universo expõe um aspecto teológico de sua ideia de infinito atual. A existência infinita, o universo infinito e o vácuo ou espaço infinito acoplam-se e quase se confundem com a Presença (Kavod) que, por preencher todo o universo, é desse modo também apresentada como manifestação do infinito atual. Esse preenchimento que permeia completamente o preenchido, mas que não se confunde com ele, é relacionada aqui à extensão, pois o Kavod preenche completamente todo o universo assim como as dimensões preenchem completamente o corpo. ${ }^{38}$ Nos capítulos da Terceira Parte do Primeiro Discurso $(\mathrm{OH} 1,3,3)$ essa mesma imanência aparece formulada na prova da existência de Deus em termos de Deus ser a causa imanente, atuando em cada etapa da série infinita de causa e efeito que gera eternamente os seres contingentes, isto é a metziut. Sua Presença constante preenche tanto o tempo eterno quanto a extensão infinita. Sua ideia de transcendência não é a mesma de Maimônides. Para Crescas, a transcendência é entendida como infinita ultrapassagem; enquanto que, para Maimônides, transcendência é entendida como diferença de substância. São duas noções diferentes da ideia de ser necessário.

Em seguida, na terceira meditação, Crescas discute a possibilidade de movimento do corpo infinito e rejeita a ideia de Aristóteles de que em um movimento circular há sempre logicamente um centro e, portanto, um corpo infinito não poderia existir em virtude de uma esfera infinita não possuir um centro. Como ela giraria em torno de um centro? Crescas critica essa argumentação demonstrando que um corpo infinito não é uma esfera, pois ele não tem figura alguma. Assim não há para ele nenhuma relação entre a forma de um corpo e o seu movimento. ${ }^{39}$

É a quarta meditação que encerra sua crítica à primeira proposição do Guia, onde é exposto mais outro aspecto relevante de sua ideia de infinito. Após examinar, na terceira meditação, a geometria do círculo infinito ${ }^{40}$ ele então aplica a geometria do círculo infinito para entender a forma e o movimento do corpo infinito para averiguar possibilidade de sua

\footnotetext{
${ }^{38}$ Crescas, 70.

39 Smilevitch, 411.

${ }^{40}$ Smilevitch, 403.
} 
existência em ato. Crescas, então, numa mudança abrupta em seu raciocínio, aparentemente propõe a possibilidade da existência de numerosos e talvez infinitos mundos finitos (olamot). Essa aparente mudança abrupta de assunto é de certo modo originada na própria tradição aristotélica (De Caelo I, 8), pois, imediatamente após discutir o problema do infinito, Aristóteles passa então para esse tema.$^{41}$ Apesar do tema ser um aspecto da crítica à primeira proposição do Guia, a discussão de Crescas realmente se dá com Gersonides e seus argumentos contra a possibilidade de existirem muitos mundos. Retomando a questão quanto à forma do volume infinito, ele argumenta que também para Aristóteles tal corpo não teria centro ou bordas. Isso é importante para entender o passo que faz a seguir. A possibilidade de existirem múltiplos mundos é consequência da possibilidade da existência ou do vácuo ou do pleno fora do mundo, em virtude de que a extensão tridimensional vai além da esfera das estrelas fixas que marca seu limite na cosmologia ptolomaica:

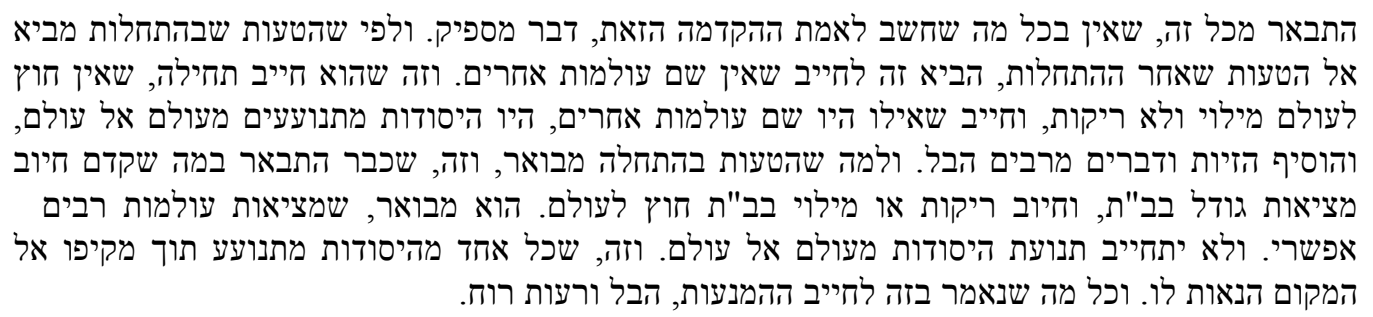

Tudo isso demonstra claramente que em todos os argumentos para provar esta primeira proposição (de que uma magnitude infinita é impossível) não há um único argumento convincente. E como um erro nos primeiros princípios leva a outros erros que seguem os primeiros princípios, a implicação desta proposição (que nega o infinito) faz com que ele conclua que não há outros mundos. Pois, tendo provado Aristóteles, para sua própria satisfação e não de modo contundente, que fora deste mundo não há nem pleno nem vácuo, argumentando, deste modo, que não há nenhum outro mundo e que, se existissem muitos outros mundos, os elementos deles se moveriam de um mundo para o outro; assim ele ajunta ilusões e argumentações vazias a muitas coisas que multiplicam a vaidade (Eclesiastes 6:11). Reconhecido o erro do princípio, uma vez que já foi estabelecida a existência necessária de uma magnitude infinita e que o cosmos é necessariamente envolvido pelo vácuo ou pelo pleno infinito, então a existência de múltiplos mundos é possível e isso não implica que os elementos de um mundo se moveriam para outro, pois, em cada mundo, seus elementos se movem dentro daquele dado mundo até o lugar que lhe é conforme. Tudo o que se afirma a este respeito para provar a impossibilidade são vaidade e aflição de espírito (Eclesiastes 1:14). ${ }^{42}$

Também na Metafísica (1074a 32), Aristóteles tenta buscar provas de que só pode existir um universo. Entre os gregos, ele não é o único com essa posição, pois também Platão

\footnotetext{
${ }^{41}$ Wolfson, 472. Na nota 126 Wolfson explica que a discussão feita por Bruno em De l'Infinito Universo et Mondi IV , 369, linhas 39 - 40 é muito semelhante à explicação de Crescas.

${ }^{42}$ Crescas, 75.
} 
advoga a unicidade do universo. Para ele, a razão seria mais de caráter teológico. ${ }^{43}$ Essa ideia era algo estabelecido na tradição filosófica medieval do ocidente latino até que a reação contra o aristotelismo e o averroísmo, contida nas condenações de Paris de 1277 que fazem menção especificamente a esta questão no contexto da discussão sobre a onipotência divina, ${ }^{44}$ fizesse com que ela voltasse a ser objeto de renovada especulação. Aquino defende a posição aristotélica, opondo-se à dos franciscanos de Oxford, como Duns Escoto e Guilherme de Ockham e, na Universidade de Paris, à de João Buridan e Nicolau Oresme, que tenderão a levantar argumento a seu favor. Também Boaventura e Francis Mayron voltaram-se para a discussão desta hipótese, mas encontravam várias dificuldades em virtude da teologia cristã considerar a encarnação de Jesus como um evento de caráter único e universal. ${ }^{45}$ Todo este debate influenciará o pensamento de Nicolau de Cusa, encontrado em seu livro que é publicado, em 1440, trinta anos depois de Or Ha-Shem. ${ }^{46}$

Sobre isso, como escrevem Musall ${ }^{47}$ e Pines ${ }^{48}$, aqui também o pensamento de Crescas está em diálogo com a escolástica e de certa forma também é herdeiro das condenações de Paris de 1277, o que demonstra que neste período a filosofia judaica está em contato com o debate travado em paralelo na filosofia medieval latina. Assim, é melhor antes aqui falar em recepção e relação do que em influência. Crescas jamais cita ou parafraseia os autores latinos. Seu argumento em prol da possibilidade de múltiplos mundos segue uma elaboração própria e é colocado como consequência e culminância do percurso que ele faz para provar, como já vimos, a possibilidade da existência tanto da grandeza imaterial quanto material infinita, porém, não coloca de forma central o tema da onipotência divina. Se há magnitude infinita, então fora do cosmos existe ou vácuo ou o pleno. E em ambos os casos este mundo não poderia estar no centro do volume infinito em virtude da constatação de que não há um centro. Desse modo, o centro do cosmos finito não é o centro absoluto do volume infinito, seja ele vácuo ou pleno. Neste caso, a objeção de Aristóteles contra a existência de múltiplos mundos, segundo a qual os elementos desses mundos tenderiam a se deslocar deles em direção ao nosso mundo, o que resultaria no final em um único mundo, não faz sentido e cai por terra. Isso por que o movimento dos elementos é considerado no aristotelismo como tendo somente duas direções naturais, para cima ou para baixo, como, por exemplo, fogo para cima e terra para baixo, estando o ar e a água entre o fogo e a terra. Quando Aristóteles argumenta que o elemento terra dos outros mundos tenderia a se dirigir para o centro de este mundo, seu raciocínio não leva em conta como a possibilidade do vácuo ou pleno infinito altera a diferença de condições, pois ele toma a lógica do finito para pensar o infinito. Crescas, que, antes, na segunda meditação, criticou a ideia de lugar natural e, portanto, a teoria peripatética que separa o movimento em natural e acidental, argumenta concedendo que a ideia de lugar natural poderia ser restrita apenas aos mundos particulares, pois, os elementos constituintes desses mundos não necessariamente se precipitariam sobre o nosso mundo "pois, é possível que em cada mundo, seus elementos se movam dentro dele até o

\footnotetext{
${ }^{43}$ Milton K. Munitz, “One Universe or Many?,” Journal of the History of Ideas 12, n. 2 (abril, 1951), 239.

44 Ibid., 240.

${ }^{45}$ Grant McColley \& H. W Miller, "Saint Bonaventure, Francis Mayron, William Vorilong, and the Doctrine of a Plurality of Worlds," Speculum, 12, n. 3 (Jul., 1937), 386-389.

${ }^{46}$ Munitz, 241.

${ }^{47}$ Musall, 135.

${ }^{48}$ Shlomo Pines, "Scholasticism after Thomas Aquinas and the Teachings of Hasdai Crescas and his Predecessors," Proceedings of the Israel Academy of Sciencies and Humanities I, n. 10 (1967).
} 
lugar que lhe é conforme" ${ }^{49}$. A ideia de lugar natural que já havia sido criticada por Crescas é aqui descartada por outra via: ou ele não existe (segunda meditação), ou ele é restrito aos mundos particulares (quarta meditação). É verdade que Gersonides já havia considerado essa hipótese e, descartado-a, Crescas aqui está, portanto, a recolocar os argumentos usados por Gersonides e a rejeitá-los. Isso por que, sobre esse assunto, ele está mais a debater com Gersonides (séc. XIV) do que com Maimônides, o que fica mais claro no final de Or Hashem (Luz do Nome Divino) na passagem dedicada ao debate sobre a existência ou não de muitos mundos (olamot rabim).

Essa discussão aparece no quarto tratado no final de seu livro. O quarto e último discurso de Or Hashem está organizado de modo diverso dos três primeiros discursos, pois, ao invés de seções e capítulos, ele se divide em treze investigações sobre a validade de crenças disputadas, que incluem, por exemplo, temas como questões sobre a eternidade do mundo, a pluralidade dos mundos, se os corpos celestes são entidades vivas e racionais ou não, a influência astral, a reencarnação, a recompensa futura de um menor, os significado de paraíso e inferno, maassê bereshit (o estudo esotérico sobre a criação do mundo) e de maassê merkavá (o estudo esotérico sobre a Presença Divina), se o intelecto, o inteligível e aquele que conhece intelectualmente podem ser um e o mesmo, o primeiro motor e o escopo da metafísica. Essas investigações são organizadas de modo dialético (pilpul) com a confrontação dos argumentos de um lado e do outro, que são primeiro expostos e depois criticados.

Na segunda investigação $(\mathrm{OH} 4,2)$, dedicada ao debate sobre se "a existência simultânea de outros mundos ou de uma pluralidade de mundos é possível", Crescas confronta os argumentos em prol da pluralidade dos mundos com os argumentos contrários de Gersonides. Os dois argumentos favoráveis são: primeiro, dada a existência do vácuo, qualquer que seja o modo como o mundo foi engendrado, pela vontade ou pela necessidade, nada impede que existam outros mundos e; segundo, se como é mais provável, foi pela vontade divina, então, ele ocorreu para difusão do bem e da magnanimidade contrário à avareza e à inveja e, assim, quanto mais o número de universos aumenta, maior é a difusão do bem e, portanto, assim é possível a existência simultânea de muitos mundos. ${ }^{50}$ Apesar de falar em muitos mundos à luz da terceira seção do primeiro discurso, na seção dedicada ao tema da alegria ou felicidade divina $(\mathrm{OH}$ 1,3,5), fica claro que o segundo argumento indutivamente está a advogar em prol de infinitos mundos. Depois de afirmar que Deus é o agente verdadeiro da existência de todos os seres de modo intencional e voluntário, perpetuando suas existências e doando sua bondade permanentemente, ele então afirma que essa atividade eterna e constante, próprio amor divino em ato, se dá conforme seu poder infinito. Harvey compartilha dessa interpretação e sobre isso nota que Crescas distingue em sua linguagem duas noções, a de metziut (existência ou universo infinito) e olam [mundo finito] ${ }^{51}$ e que essa conclusão já é encontrada também em Wolfson. ${ }^{52}$

Os argumentos contrários à existência de muitos mundos, tirados de Gersonides, são, em primeiro lugar, os de que, se há muitos mundos, então, ou há o vácuo ou o pleno entre

\footnotetext{
${ }^{49}$ Crescas, 76.

${ }^{50}$ Ibid., 378 - 379.

${ }^{51}$ Warren Zeev Harvey, Physics and Methaphysics in Hasdai Crescas. Col. Amsterdan Studies in Jewish Thought (Amsterdan, J.C. Gieben Publisher, 1998), 8.

52 Wolfson, $117-118$.
} 
eles, mas, como os antigos demonstram que o vácuo é impossível, então temos o pleno. Esse corpo entre os mundos ou é transparente ou opaco, se transparente, então deveríamos poder ver os outros sóis e luas desses mundos, se opaco, deveríamos poder perceber, pelo menos, sua luz difusa. Em segundo lugar, temos que se a multiplicidade só ocorre entre os seres corruptíveis, animais e plantas, portanto, uma vez que o mundo é incorruptível, então só pode haver um. Em terceiro lugar, temos que o agente da totalidade da existência é uma unidade de uma simplicidade extrema e do um simples só pode provir o um simples. Em sua crítica desses argumentos, Crescas aponta que, em primeiro lugar, a existência do vácuo não é uma hipótese absurda, pois a possibilidade de sua existência foi demonstrada; em segundo lugar, um raciocínio analógico não é uma prova, porque afirmar que a pluralidade é encontrada entre os seres corruptíveis não prova que ela não possa existir entre os seres incorruptíveis; em terceiro lugar, o argumento derivado da perfeição do agente não impede a pluralidade de mundos, se cada um for distinto dos outros. Crescas, no entanto, admite que não é possível provar cabalmente a existência de outros mundos uma vez que ela é apenas uma necessidade da razão que vem como corolário da possibilidade da existência da magnitude infinita. Aqui então ele apresenta um argumento oriundo da tradição rabínica que é sui generis, mas certamente de peso entre os leitores judeus da academia rabínica a quem ele se dirige, que é o de que, em um midrash encontrado no Talmud, no tratado de Avodá Zará 3b, é dito que a providência divina atua simultaneamente em dezoito mil mundos. Em outras palavras, segundo sua interpretação, os primeiros rabinos também afirmariam a pluralidade de mundos, mas, no entanto, eles também eram de opinião que sobre este tema não há como termos, ou como poderíamos obter, conhecimento cabal. Neste ponto, ele encerra sua crítica da primeira das proposições do Guia que rejeitam o infinito atual, terminando por tecer vários aspectos de sua ideia de infinito atual em Deus e no mundo, ou seja, o infinito como elo entre imanência e transcendência, isto é, sua ideia de magnitude infinita.

\section{O Infinito como Singularidade}

Relembrando, na segunda proposição do Guia dos Perplexos, Maimônides afirma:

\section{השנית שמציאות בעלי שיעור אין תכלית למספרם שקר, והוא שיהיו נמצאים יחד:}

Segunda proposição: A coexistência de um número infinito de magnitudes finitas é impossível. ${ }^{3}$

Em sua crítica a esta proposição, Crescas vai ao longo de sua argumentação apresentar mais um aspecto importante de sua ideia da existência de infinito em ato, a saber, que o infinito não pode ser descrito como par ou ímpar. Ele principia por afirmar que a refutação da primeira proposição já subentende a refutação da segunda, pois a existência de um número infinito de seres finitos é um caso particular da possibilidade de uma magnitude infinita em ato. Mas como há quem afirme que mesmo que a primeira proposição não possa ser conclusivamente estabelecida, a segunda poderia ser estabelecida baseada no argumento da

\footnotetext{
${ }^{53}$ Moshé Maimonides, 159
} 
impossibilidade de existir um número infinito em ato, em assim sendo, então, é necessário discuti-la em separado. Crescas enuncia o argumento dessa objeção com as seguintes palavras:

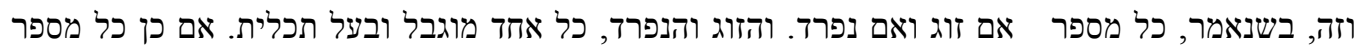

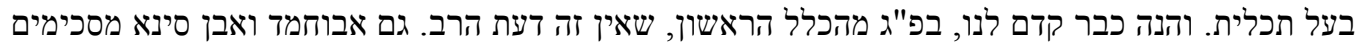

Que não é possível existir um número infinito é demonstrado pelo seguinte raciocínio: Todo número [mispar] ou é par ou ímpar. E, se par $[z u g]$ ou ímpar [nifrad], então cada número é limitado [mugbal] e finito [baal takhlit]. Assim, todos os números são finitos. Em resposta a isso, nós podemos nos referir ao que já foi dito no capítulo três da primeira seção $(\mathrm{OH}, 1,1,3)$, que este não é o entendimento do Mestre [she-ein zé daat há-rav] (Maimônides). Também Abuhamed (Al Gazali) e Ibn Sina (Avicena) concordam com ele. ${ }^{54}$

Em primeiro lugar, contesta que este seja o entendimento que o próprio Maimônides e os filósofos árabes mais antigos tivessem da segunda proposição. A referência nessa passagem é feita à posição advogada por Maimônides e Avicena de que somente um número infinito de seres materiais é impossível, enquanto que o número dos seres imateriais poderia ser infinito, pois não são contáveis. Maimônides nega que possa existir uma cadeia infinita de causa e efeito não apenas com relação aos seres materiais, mas também entre os seres imateriais, embora os seres imateriais possam ser infinitos em potencial, uma vez que são incontáveis. Crescas atribui a Averróis esta outra interpretação da segunda proposição segundo a qual os números devem ser finitos porque, por definição, todo número é par ou ímpar. Ou seja, sabemos que um número é par ou ímpar após tê-lo contado e que, se tudo que pode ser contado e que é atualmente contado é definido e limitado, então conclui-se que não pode existir um número infinito de elementos em qualquer conjunto. Essa argumentação de Averróis está em seu Comentário Intermediário à Física III. Crescas, que leu Averróis da tradução do hebraico dos Comentários Médios ${ }^{55}$, parafraseia quase o citando com as seguintes palavras:

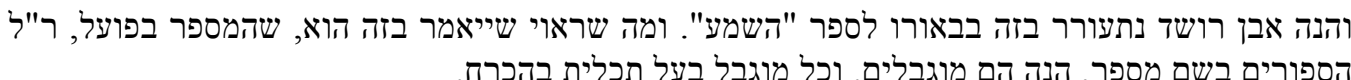

E eis que é Ibn Rushid [Averróis] que se inquieta com este problema em seu Comentário [bevaoro] sobre a Física [lesefer há-shemá], com o que pode ser enunciado assim: um número em ato [she há-mispar befoal], ou seja, são limitadas [mugbalim] as coisas computadas [sipurim] por uma cifra [be-shem mispar]. E tudo o que é limitado é forçosamente finito [takhlit be-hekhreah]. ${ }^{56}$

\footnotetext{
${ }^{54}$ Crescas, 76.

55 Wolfson, 477. Olhar nota 3.

${ }^{56}$ Crescas, 76.
} 
Depois de Averróis, um argumento semelhante é também feito com concisão por Gersonides no Sefer Milkamot Há-Shem 6, 11. Segundo ele, a magnitude deveria ser finita, pois, todo e cada número é necessariamente delimitado e, portanto, finito. Sabemos que todo número é delimitado porque, ao ser atualmente contado, cada número é par ou ímpar, seja ele múltiplo, primo ou composto, ou tenha ele qualquer outra propriedade que um número possa ter, porque, se essa regra não se aplicar a todos os tipos de números, então um deles deveria ser infinito por necessidade, pois ele não seria delimitado, o que já foi demonstrado como sendo falso. Como o infinito poderia ser contado? Desse modo, conclui Gersonides, seguindo Averróis:

\section{וכן נאמר שהמספר הוא בעל תכלית, לפי שכל מספר הוא אם זוג, אם נפרד, וזהו תכליתו.}

E assim é dito que o número é finito, pois, todo número é par ou é ímpar e isso implica que ele é finito (ou isso implica sua finitude). ${ }^{57}$

Para Rabinovitch, Gersonides (séc. XIII) vislumbrou a implicação da possibilidade de que a regra de que todo número, por ser contado, é finito, poderia não se aplicar a todo tipo de número e, contudo, recuou, por não aceitar a necessária conclusão. Esse argumento, no entanto, já fora proposto antes de Maimônides (séc. XII) e Gersonides, por Abraham Ibn Daud (séc. XII), para quem é impossível que exista um número infinito de objetos contados ou ordenados, porque dizer que são contados significa que sejam um número específico, mas, se são infinitos, então significa que não é possível para alguém contá-los e, assim, chegar a um montante específico, pois, seria um absurdo dizer: "Eu contei o infinito e cheguei ao fim daquilo que não tem fim". ${ }^{58}$ Também, segundo ele, afirmar que um conjunto infinito possa ser ordenado é absurdo, por quanto a existência de ordem no infinito é uma contradição. Assim, conclui Ibn Daud que a existência de um conjunto atual formado por infinitos objetos ordenados seria o equivalente a existir um conjunto de objetos que são ao mesmo tempo ordenados e desordenados, ou seja, isso seria o mesmo que fazer um enunciado ao mesmo tempo positivo e negativo, o que é contraditório e, portanto, falso. ${ }^{59}$ Conclui então Ibn Daud que número natural é, desse modo, finito.

Frente a estas objeções à existência de um número infinito Crescas tenta uma primeira resposta que será logo em seguida rejeitada por ele mesmo:

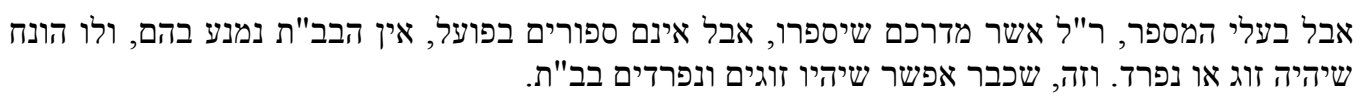

No entanto, coisas que possuem número [baalei hamispar], ou seja, que são da sua natureza [midarkam] serem numeradas [sheissafru], mas que não são atualmente numeradas [sepurim befoal], para estas, a infinitude não é impossível. É

\footnotetext{
${ }^{57}$ Gersonides, Sefer Milkamot Há-Shem 6, 11 (Jerusalem: Há-Otzar: Há-Otzar Sefarim Há-Yehudi Versão 16, DBS, 2011), sp.

${ }^{58}$ Ibn Daud Emuna Rama 1,4 (Jerusalem: Há-Otzar: Há-Otzar Sefarim Há-Yehudi Versão 16, DBS, 2011), sp. Rabinovitch, N.L., Rabbi Hasdai Crescas (1340 - 1410) on Numereica Infinities, 227.

${ }^{59}$ Ibid.
} 
até mesmo possível assumir que sua quantidade seja par ou ímpar, pois é possível existirem infinitos números pares ou infinitos números ímpares. ${ }^{60}$

Por que esta solução é rejeitada? Conforme nota Wolfson, ${ }^{61} \mathrm{o}$ argumento de Crescas se contrapõe à passagem da Física III, 5, 204b 7-10, na qual Aristóteles afirma que, "Tampouco é possível existir um número infinito em separado ${ }^{62}$, pois número, ou aquilo que tem número, é numerável. Se fosse possível numerar o que é numerável, então seria possível contar o infinito"63. Na tradução medieval hebraica desta passagem da Física a palavra usada para número é mispar, e a expressão usada para traduzir "aqueles que têm número" é baalei hamispar. Crescas distingue aqui entre "aqueles que têm número" (baalei hamispar) e número (mispar) e, se opondo à tradição aristotélica, afirma que eles são conceitos diferentes. O número pode ser finito enquanto as coisas numeráveis, não. Mas esse raciocínio faz com que "aqueles que têm número" (baalei hamispar) sejam infinitos apenas em potencial, não em ato, pois se todas forem numeradas, então serão finitas. A indeterminação seria referente à possibilidade de realizar a conta. Como bem ressalta Smilevitch ${ }^{64}$, a questão de Crescas é provar a existência do infinito em ato e não apenas em potencial, como aquilo que pode ser numerado, mas não o é. Mas se realizada a conta chegássemos ao infinito, então, se assim fosse, teríamos a possibilidade do infinito par ou do infinito ímpar. Mas a questão para Crescas não é apenas quanto à possibilidade ou não do espírito contar um conjunto, mas a da possibilidade da existência em ato de um conjunto infinito. É assim que Crescas então propõe outra solução:

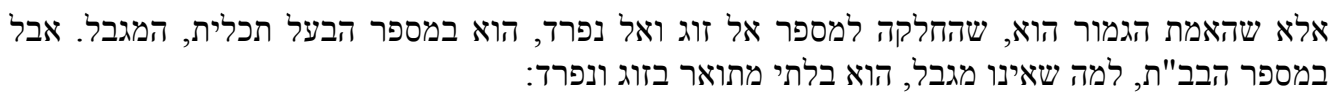

Todavia, a verdade plena é que a divisão dos números em par ou ímpar só se aplica ao número finito [baal takhlit] e, desse modo, limitado [hamgubal]. No entanto, o número infinito, justamente por ser limitado, não é possível descrevêlo [metoar] como par ou ímpar. ${ }^{65}$

O número infinito é singular, ou seja, podem existir infinitos números pares ou ímpares, mas uma quantidade infinita não é passível de ser descrita nem como par nem como ímpar. À parte noções já propostas do infinito como imensurável e como incognoscível, Crescas propõe agora outra característica que o distingue dos números naturais que são limitados. Se à noção do infinito como imensurável corresponde a expressão bíblica e talmúdica ein-mispar e, à noção de incognoscível corresponde a expressão ein-heker, o infinito é agora entendido mais claramente em sua distinção radical do limitado e, portanto, como einketz (sem limite). Contudo, aqui novamente, não se trata da simples aplicação das noções

\footnotetext{
${ }^{60}$ Crescas, 76.

${ }^{61}$ Wolfson, 478. Olhar a nota 6.

62 Por "número separado" é entendido nesta passagem uma totalidade numérica atual, e não meramente potencial. Ver comentário de Guillermo Echandia, à Física.

${ }^{63}$ Aristóteles, Physics, $281-282$.

${ }^{64}$ Smilevitch, 413-414. Olhar nota 1.

${ }^{65}$ Crescas, 76.
} 
bíblicas e rabínicas, pois seu trato do tema excede no rigor ao modo como essas tradições sapienciais judaicas lidaram com o problema do infinito e, desse modo, por dialogar para além da literatura tradicional judaica com os gregos e a falsafa, sua obra está de fato no campo da filosofia. Pois a distinção entre a filosofia judaica medieval e as outras tradições sapienciais judaicas é que ela não está apenas em diálogo com a tradição, mas em claro e aberto diálogo com autores gentios, gregos ou árabes.

O argumento usado por Averróis e Gersonides, isto é, pela tradição aristotélica para rejeitar a possibilidade da existência de uma quantidade infinita de seres finitos, é criticado por Crescas mais uma vez por conceber o infinito nos termos do finito. Quando o trato matemático do infinito é depurado e estabelecido em bases diversas das deles, sua atualidade se mostra possível, enquanto que o que não é possível é reduzir o infinito aos termos do finito, isto é, o infinito é singular.

\section{A Série Infinita de Causa e Efeito}

O enunciado que Maimônides fez das 26 proposições é escrito de forma elegante e concisa, como, aliás, é também seu estilo no Mishné Torá. Ele escreve assim todas as vezes que considera o assunto como já conhecido e provado e não se preocupa em trazer novos argumentos nem apresentar os de seus predecessores. Esse estilo de argumentar e escrever, no entanto, lhe rendeu muitas críticas, em especial nas academias rabínicas, pois a cultura de estudos destas frisava já há muitos séculos a necessidade de sempre citar as fontes. Diz o ditado rabínico que "quem cita a fonte traz redenção ao mundo". Maimônides, porém, prefere alongar-se no debate e argumentar apenas onde lhe parece necessário. Vejamos esse estilo exemplificado no enunciado da tradução em hebraico da terceira proposição traduzida por Ibn Tibon, que foi aquela lida por Crescas:

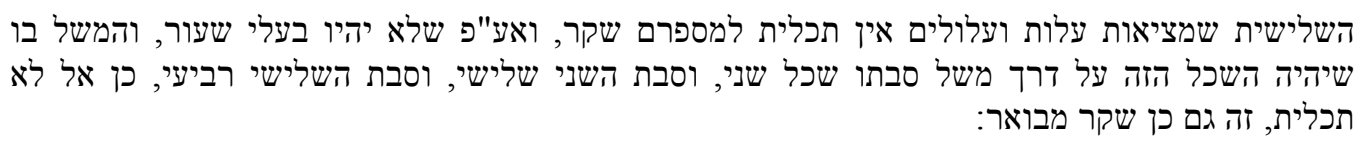

Terceira proposição: A existência de um número infinito de causas e efeitos é impossível, ainda que não sejam magnitudes. Se por exemplo um intelecto fosse a causa de um segundo, o segundo a causa de um terceiro, o terceiro a causa de um quarto e assim por diante, as séries não poderiam continuar até o infinito, pois é uma clara falsidade.

Esta proposição afirma de modo conciso que uma série infinita de causas e efeitos é impossível, ainda que seja uma série formada por seres imateriais, mas a proposição não fornece nenhum argumento, ainda que breve em apoio à afirmação. Isso fez com que nos séculos seguintes ao aparecimento de sua obra surgissem diversos comentadores que buscaram preencher esta lacuna apresentando a possível argumentação para diversas passagens como esta. No caso do Guia dos Perplexos, apesar de escrito originalmente em árabe, a maioria dos seus comentadores medievais era formada de leitores judeus. No entanto, foi $\mathrm{Mu}-$ hamad Al-Tabrizi, muçulmano, persa, que viveu no século XIII, quem escreveu um dos comentários às 26 proposições que se tornaram mais divulgados nas academias rabínicas oci- 
dentais medievais. Ele chegou até mesmo a receber duas diferentes traduções para o hebraico. Crescas usa diversas vezes o comentário de Al-Tabrizi para apresentar os argumentos em prol das 26 proposições, principalmente na Primeira Seção do Primeiro Tratado de Or Hashem $(O H 1,1)$ dedicada justamente à apresentação dos argumentos que embasam a posição aristotélica.

Crescas nem sempre cita Al-Tabrizi e muitas vezes apenas o parafraseia. Segundo a leitura que ele faz, o persa explica a terceira proposição do seguinte modo: uma série infinita de seres que guardem entre si alguma ordem (seder) ou posição (matzav) de magnitudes (gedolim) na natureza (ba-teva) de tal modo que a relação entre eles seja de causa (ilá) e efeito (alul) é impossível, porque uma causa é aquilo cuja existência implica a existência do efeito e, se fosse concebida a não existência da causa, o efeito não também existiria. ${ }^{66}$ É esta relação entre causa e efeito que torna impossível, segundo a tradição aristotélica, uma série infinita de causas e efeitos. Isso porque segundo esta posição:

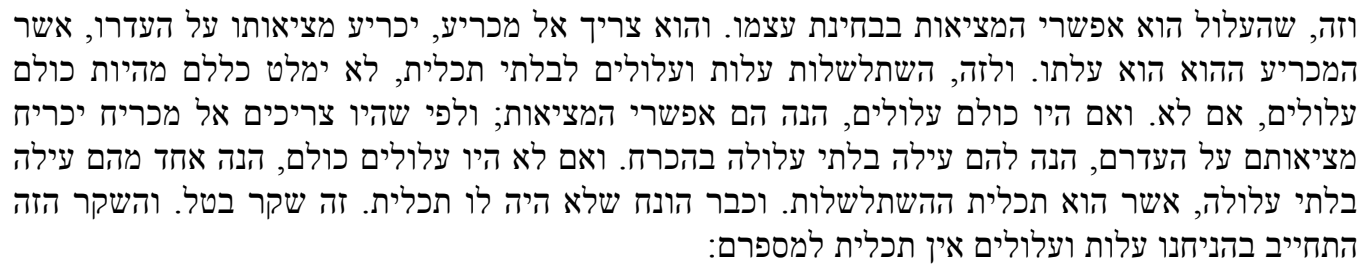

O efeito [alul] tem apenas uma existência possível [efshari hametziut] por si mesmo. Assim sendo, então, ele precisa de um determinante [makhriah] que determine [iakhriah] a preponderância da sua existência [metziuto] sobre a não existência [hedero $]^{67}$ e esse determinante é sua causa. Por isso, inevitavelmente, numa série infinita [levilti takhlit] de causas e efeitos ou todos os elementos são efeitos ou alguns não são efeitos. E se todos forem efeitos, têm apenas existência possível [efshari hametziut], pois necessitam de um determinante [makhriah] que determine [iakhriah] a preponderância da existência [metziutam] deles sobre a não existência [hederam], o que pressupõe a existência de uma causa não causada [ilá bilti alua]. Mas se eles não são todos efeitos, pois um deles é uma causa não causada, ela mesma marca o limite da série. Mas a série foi concebida como infinita, e isso é uma contradição [sheker batel]. E tal contradição só ocorre por termos admitido a existência de uma série infinita [ein takhlit lê misparam] de causas e efeitos. ${ }^{6}$

A argumentação de Al-Tabrizi se apóia por um lado em duas passagens da obra de Aristóteles, uma da Física VIII, 5 256a e outra da Metafísica $\alpha, 2$ em que o pensador grego argumenta contra a possibilidade de uma série infinita afirmando que, se não há primeiro termo, não há causa para a série e, além disso, Al-Tabrizi se apoia na distinção feita por Avicena, que era também persa, entre ser necessário e ser contingente, para provar a impossibi-

\footnotetext{
הנה אחר שביאר בהקדמה השניה, המנעות מציאות בב"ת בדברים אשר להם

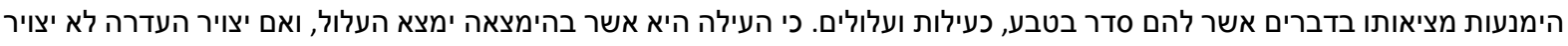
מציאות העלול.

${ }^{67}$ Literalmente, em hebraico, falta de forma, estado amorfo.

${ }^{68}$ Crescas, 33.
} 
lidade de uma série infinita de causas e efeitos. Como os efeitos têm apenas existência possível, pois sua causa está fora deles, assim, podem tanto existir como não e então os efeitos necessitam de uma causa não causada para determinar sua existência. Essa causa é concebida como anterior a todos os outros elementos da série e é, portanto, logicamente colocada no começo da série e assim ela é a primeira causa que gera a série toda. Se há uma primeira causa, a série é então apenas potencialmente infinita para um lado, mas ela nunca será infinita em ato, o que só ocorreria se não tivesse começo.

Entretanto, ressalta Crescas, a terceira proposição, tal como entendida por Maimônides, restringe apenas a impossibilidade de um número infinito de efeitos para as coisas que são regidas por uma ordem posicional tal como as magnitudes, ou por coisas regidas por uma ordem natural, tal como as causas e os efeitos necessários. No entanto, os intelectos e as almas, por serem concebidos por Maimônides como não possuindo nem ordem posicional nem ordem natural, não teriam nenhuma restrição à possibilidade de serem infinitos. De fato, essa posição é afirmada no Guia em duas passagens. A primeira delas está no Guia 1,74, onde em sua crítica à tese do kalam segundo a qual o número de almas é finito, Maimônides escreve:

אמנם קצת אחרוני הפילוסופים התירו זה הספק בשאמרו, הנפשות הנשארות אינם גשמים שיהיה להם

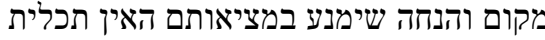

Contudo, alguns filósofos mais recentes resolveram este problema com o seguinte argumento: as almas imortais não são substâncias corporais que ocupam um lugar e guardam posição (entre si), o que as impediriam de existir em número infinito. ${ }^{69}$

A segunda passagem em que Maimônides apoia a possibilidade de uma única causa poder ter mais de um efeito aparece em meio à discussão acerca da criação versus eternidade do mundo no Guia II, 22, onde ele escreve:

כי כל פועל שיפעל בכוונה ורצון לא בטבע, יעשה פעולות מתחלפות רבות:

Pois todo agente que age com vontade (intenção) e não apenas pelas leis da natureza é capaz de produzir muitos efeitos. ${ }^{70}$

Este é, aliás, o único caso em que Maimônides aceita a possibilidade do infinito: Deus o agente que age por vontade livre pode criar infinitas almas, que são assim, cada uma delas um efeito simultâneo da ação do agente. Crescas nota que esta também é a opinião de Avicena e Al-Gazali. ${ }^{71} \mathrm{O}$ único que nega tal possibilidade é Averróis, pois para ele um número infinito não poderia existir em ato em virtude de que, segundo sua opinião, todo número deve ser par ou ímpar, mas esta objeção averroísta já foi descartada na crítica à segunda proposição. A argumentação de Crescas em prol da possibilidade de uma série infinita de

\footnotetext{
${ }^{69}$ Moshé Maimonides, 74.

70 Ibid., 22.

${ }^{71}$ Crescas, 77.
} 
causas e efeitos vai levar em conta, por um lado, a restrição de Al-Tabrizi segundo a qual é necessária uma primeira causa não causada que determine a existência da série e, por outro, a possibilidade, aceita por alguns filósofos, entre eles Maimônides, de que um agente que age por vontade própria possa causar infinitos efeitos. ${ }^{72}$ Assim, Crescas escreve em $\mathrm{Or}$ Hashem 1,2,3 que, se é possível para uma causa que age por vontade, emanar infinitos efeitos então:

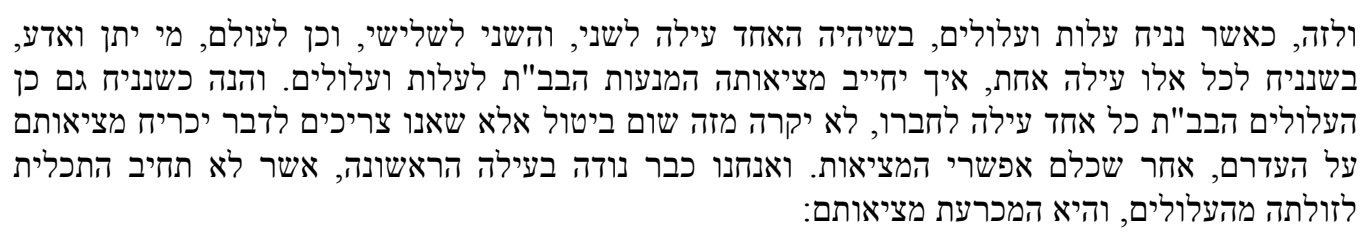

Sendo este o caso, quando ordenamos uma série de causas e efeitos de tal modo que o primeiro seja causa do segundo e este do terceiro e assim para sempre, não encontro nenhuma razão que se saiba para (objetar) que, supondo uma causa única comum para todos os elementos da série, o número de causas e efeitos não possa ser infinito. E eis que, quando ordenamos uma série infinita com cada um sendo a causa do seguinte, também neste caso não há nenhuma contradição, levando em conta que precisamos falar em um determinante que faça prevalecer sua existência sobre sua não existência, pois todos têm apenas existência possível. Todavia já sabemos de uma causa primeira que não é o limite da série dos efeitos e ela é o determinante para suas existências. ${ }^{73}$

O texto de Crescas, mesmo em hebraico, parece argumentar de modo incompleto e obscuro. Conforme Wolfson, o argumento de Crescas seria o seguinte:

Suponhamos uma causa não causada e eterna, portanto, um ser necessário, capaz de produzir infinitos efeitos. Suponhamos também que estes efeitos coexistem com a causa infinita. Por que estes efeitos não poderiam ser arranjados numa série em que cada um aparece depois do outro mantendo entre si uma relação de causalidade acidental? Cada elemento deve sua existência à causa comum que é imanente a toda a série e simultânea em relação a cada um deles ao mesmo tempo em que eles surgem, um após o outro, mantendo entre si uma relação de causalidade acidental. Essa série poderia ser infinita, pois a primeira causa não é apenas causa do segundo elemento da série e este do terceiro e assim por diante, marcando assim o limite da série, mas é causa comum à série inteira, que assim poderia ser infinita, apesar de composta por seres contingentes. Como no exemplo lembrado por Smilevitch $^{74}$, o sol nasce e o camponês levanta-se para ir trabalhar no campo. Nesse exemplo, o evento nascer do sol precede o segundo evento o camponês se levantar para ir ao campo, mas aqui não há uma causalidade necessária, ela é meramente acidental, eles apenas estão ordenados em sucessão e, no entanto, a causa comum a todos eles é simultânea à existência

\footnotetext{
וזה, שלא יחויב המנעות מספר בב"ת אלא לדברים שיש להם סדר והדרגה : במצב או בטבע. ולזה, אפשר בשכל אחד שיהיה עילת שכלים בב"ת במספר.

${ }^{73}$ Crescas, 77.

${ }^{74}$ Smilevitch, 418.
} 
de cada um. A primeira causa tem para com eles uma anterioridade ontológica e não meramente temporal. Isso é esclarecido por Crescas na continuação de sua argumentação em que ele comenta outra objeção à existência atual de uma série causal infinita que é levantada por Moisés Narboni:

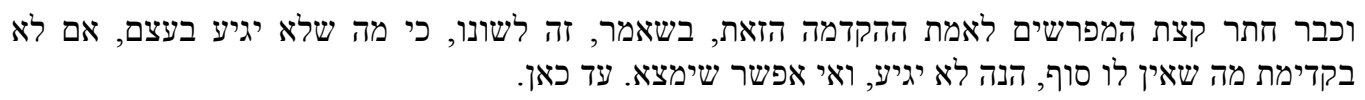

Um dos comentadores (Narboni) tentou provar esta proposição com as seguintes palavras: Aquilo que não pode ser realizado senão por meio de uma anterioridade infinita [she-ein lo sof], que o preceda, nunca chegará a ocorrer e nunca existirá. ${ }^{75}$

O argumento da afirmação vem do seguinte raciocínio: Numa série causal infinita, todos os elementos são também efeitos e por isso têm apenas existência possível (efshari hámetziut). Esquecendo por um instante o problema da necessidade de existir uma primeira causa sem causa para dar início à série, se todos os elementos têm apenas existência possível, então cada um pode existir ou não, até gerar o efeito seguinte à série. Basta um elemento não gerar o seguinte para a série acabar. Seria possível imaginar uma série assim e dizer que ela vem desde uma antecedência infinita continuando, e que esse evento de um elo da cadeia não causar o outro ainda não ocorreu. Todavia, afirma Narboni, se a série tem uma antecedência infinita, então, numa duração infinita, todas as possibilidades já ocorreram e, portanto, ela já teria sido descontinuada. Uma série assim nunca poderia ser atual.

Em sua crítica desta objeção, Crescas afirma que haveria alguma base para essa objeção de Narboni, se fosse o caso de uma anterioridade temporal/cronológica ${ }^{76}$ em que as causas precedem os efeitos no tempo. Ele faz aqui alusão aos diversos modos como pode ser conceituada a ideia de anterioridade. A origem dessa discussão está em Aristóteles ${ }^{77}$, mas Crescas aqui se refere mais diretamente a esta mesma discussão feita por Maimônides em um tratado conhecido como Milot Hahigaion (Palavras de Reflexão) ${ }^{78}$, onde ele também descreve as cinco categorias de anterioridade ou prioridade (kadmut). Dessas cinco categorias de anterioridade, duas são mais importantes para nossa discussão: a kadamá zmanit, a anterioridade temporal/cronológica, e a kadmá besibá, a anterioridade causal. O exemplo dado por Maimônides para ilustrar a anterioridade temporal é o seguinte: Noé é anterior a Abraão, que é seu descendente, assim, Noé deve ter nascido antes de Abraão. A anterioridade causal é quando um elemento é a razão da existência do outro, podendo precedê-la ou sendo-lhe simultânea. O exemplo usado por Maimônides ${ }^{79}$ é interessante, pois se refere a uma situação de existência simultânea: O nascer do sol precede a luz do dia ainda que os dois apareçam juntos porque esta é a causa daquela ainda que eles sejam simultâneos. Em tal tipo de ante-

\footnotetext{
${ }^{75}$ Crescas, $\mathrm{OH} \mathrm{1,2,3.}$

${ }^{76}$ Moshé Maimonides, 159. והנה, אם היתה הקדימה זמנית, היה מקום לטענה הזאת. ואם כבר תקבל מחלקת

77 Aristóteles, Categories 12-13. Col. Great Books of the Western World (Chicago, London, Toronto: Enciclopaedia Britannica, Inc, 1955), 19-20.

${ }^{78}$ Poderia ser também traduzido como Livro da Lógica.

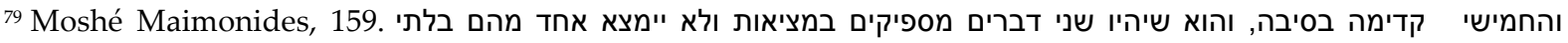

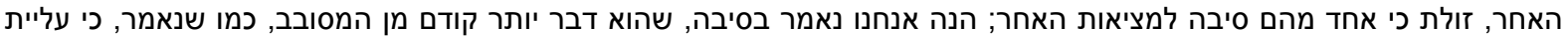

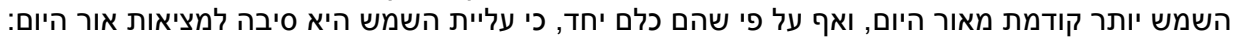


cedência, ainda que a causa e o efeito existam simultaneamente, pois ele é aquele sem o qual o outro não pode existir, ainda que tendo uma existência simultânea, lhe é anterior, porque é sua causa. Wolfson traduz como anterioridade essencial, sublinhando que ela se refere à razão da existência do ser de algo.

Como vimos, Crescas retruca Narboni, afirmado que este último teria razão se fosse o caso de uma anterioridade temporal. Porém, aquilo que Narboni nega como impossível já ocorre. Para aqueles filósofos que, como Narboni, afirmam a eternidade do mundo, o dia de hoje é necessariamente precedido de uma antecedência infinita. Dizer, como faria Narboni, que essa antecedência é apenas acidental (be-mikre) é apenas um meio de escamotear o problema.

לאומרים בקדמות העולם. אלא שזה במקרה. ושנודה באפשרות שבמקרה ובהמנעות אשר בעצם צריך האמתה.

Para aqueles que afirmam a eternidade do mundo e que, no entanto, dizem que é por acidente. Mas afirmar que algo é possível apenas quando acidental [bemikre], e impossível quando essencial [be-etzem], é uma afirmação que carece ser provada. $^{80}$

Todavia, ainda que esta distinção entre acidental e essencial seja verdadeira, ela só o seria para uma série causal onde a antecedência é temporal. Mas ela não é válida no caso de uma antecedência causal ( $k a d m u t$ be-sibá) em que causa e efeito são simultâneos, como no tipo de série infinita que propõe Crescas, em que a causa primeira é simultânea com todos os efeitos da série. Novamente, se uma causa pode produzir infinitos efeitos, tanto faz se eles coexistem no tempo ou se os efeitos estão arranjados entre si como causa e efeito acidental um do outro. A causa primeira é simultânea e imanente a toda a série e sua prioridade é, assim, essencialmente ontológica. Ela é o elemento que determina a preponderância da existência sobre a inexistência de cada elemento da série e, neste sentido, ela é primeira, isto é, antecedente a todos os efeitos.

Em Crescas, esta discussão serve para estabelecer a necessidade da primeira causa. Essa primeira causa é Deus. No capítulo dois da terceira seção do primeiro discurso de Or Hashem, essa mesma discussão remete à prova da existência de Deus como causa determinante que privilegia a existência dos entes em relação à sua inexistência. Essa mesma prova será citada por Espinosa na sua Carta sobre o Infinito. Isso, no entanto, será tratado de modo mais aprofundado em um futuro artigo sobre as críticas de Crescas às provas para existência, unidade e incorporeidade de Deus e as provas alternativas que ele propõe.

Esta passagem em que Crescas cita Narboni e com ele debate tem outra peculiaridade importante. Na maior parte do seu livro, Crescas usa apenas duas expressões para se referir ao infinito. A primeira delas é a expressão ein takhlit (sem limite), que é a expressão usada na tradução que Ibn Tibon fez do Guia dos Perplexos, do árabe para o hebraico, decalcando a expressão árabe lâ-mutanâhi, usada originalmente por Maimônides. A segunda expressão usada largamente por Crescas é bilti baal takhlit (aquele que não tem limite) que, como vimos, é introduzida na linguagem filosófica medieval hebraica por Gersonides. Vi-

${ }^{80}$ Crescas, 77. 
mos também que apesar de não serem diretamente usadas, as expressões mais antigas ein mispar, ein heker, e ein ketz, usadas na literatura bíblica e continuadas na Mishná, no Talmud e no midrash, são utilizadas no conceito de infinito que Crescas vai tecendo ao longo de sua crítica às três primeiras das 26 proposições do Guia. No entanto, uma única expressão hebraica para o infinito não fora até agora usada: a expressão ein-sof (infinito), com sua variante ein lo/lahen sof. Como vimos, tal expressão é a única usada na literatura dos primeiros rabinos tanaim e amoraim, na Mishná, no Talmud e no Midrash, que não é de origem bíblica, mas uma expressão que aparece primeiro nesta literatura escrita entre os séculos III e VI e que vai ser usada de modo eminentemente teológico no Sefer Yetzirá e nos comentários que foram feitos a esse livro na Idade Média até o século XV. A partir do final do século XII e durante o XIII, a expressão ein-sof vai se popularizar na nova literatura mística judaica da cabala medieval, sobretudo nos escritos de Azriel de Gerona e na literatura tecida em torno do Zohar. Vimos também que essa expressão aparece nas traduções para o hebraico de filósofos como Saadia Gaon, que comenta o Yetzirá, e nas traduções dos textos dos filósofos neoplatônicos. Mas em geral, ela não está presente nos textos aristotélicos em traduções e produções feitas depois de Maimônides. Certamente, a linguagem da tradução do Guia, exerceu uma enorme influência, nas traduções feitas da obra de Aristóteles e de Averróis e teve enorme impacto na linguagem filosófica hebraica medieval em seu segundo período, entre os séculos XIII e XV, quando o hebraico passou a ser a principal língua filosófica judaica medieval.

Em paralelo à trajetória da composição desta literatura filosófica judaica, outras literaturas sapienciais judaicas também eram compostas em ambientes diferentes das mesmas academias rabínicas, que são a literatura talmúdico-jurídica e a das escolas místico-cabalistas. Essa efervescência intelectual ocorria, então, na Provença, sobretudo em Aragão, onde se localizavam as academias de Gerona e de sua vizinha Barcelona, no tempo de Crescas. Ainda que pouco usada na literatura filosófica, a expressão ein-sof, com suas variantes, continuou tendo um uso mais comum nessas outras literaturas sapienciais. Apesar de serem geradas em círculos oponentes, em Crescas, essas literaturas rivais são colocadas em diálogo. Desse modo, é interessante que ele não tivesse até agora usado a expressão ein-sof. Isso, no entanto, diz muito sobre o modo como Crescas organiza seu pensamento e tece seu argumento. As expressões ein takhlit e bilti baal takhlit, que mais aparecem ao longo de seu livro, são, quando olhamos atentamente nas passagens, retiradas da linguagem de seu interlocutor, que é em geral no contexto de sua argumentação também seu oponente. Assim, ele usa ein takhlit, quando se refere à linguagem de Maimônides e de Averróis; e bilti baal takhlit, quando se refere à linguagem de Gersonides. Aqui ele usa ein sof por ser esta a linguagem empregada por Narboni em seu comentário ao Guia dos Perplexos. Nesta passagem, Narboni, que tinha um espírito eclético, pois, era seguidor de Averróis, mas que, no entanto, também escreveu um comentário sobre o texto místico Shiur Komá. Narboni, que nasceu em Perpignan e viveu em Toledo e Valência, usa indistintamente ein takhlit e ein sof para falar do infinito. Até aqui, no debate com aqueles que negam tal possibilidade, Crescas está sendo coerente com o modo como ele usualmente discutiu com vários aspectos oponentes da possibilidade do infinito atual. Como já mencionado, esse modo de argumentar, seguindo a linguagem do oponente, é encontrado na disputatio escolástica, mas é mais frequente no pilpul, isto é, dialética talmúdica. Nissin Gerondi, seu professor de Talmud, já emprega comumente esse método antes de Crescas. Seu hidush (inovação) é usá-lo no debate filosófico judaico. Diferente de Maimônides, que introduziu o organon aristotélico no mundo do beit-midrash (casa de 
estudos); com o Mishné Torá, quando se dirige aos seus colegas da casa de estudos, Crescas usa a própria dialética talmúdica para filosofar.

Além desse aspecto como metodologia de debate, o uso de diversas expressões para se referir ao infinito vai criando certo volume na ideia de infinito atual de Crescas, pois assim vão sendo percebidos ao longo de sua exposição diferentes aspectos de seu modo de concebê-lo. O infinito, como é sabido, é uma ideia muito difícil de ser conceituada. Segundo Lévinas, "pensar o infinito é pensar mais do que se pode pensar"81. No caso do hebraico medieval, esse uso de diversas expressões vai como que outorgando dimensões e complexidade à ideia de infinito. Assim, o ein takhlit (sem definição), o bilti baal takhlit (aquele que não é definido), o ein ketz (sem limite), o ein mispar (inumerável), o ein heker (insondável) e o ein sof (sem fim) vão se entrelaçando na literatura judaica medieval. Em Crescas, esses vários aspectos do infinito vão dando volume à possibilidade do infinito atual por ele defendida.

É importante ressaltar que o uso de várias expressões nos permite perceber não apenas a inter-relação entre as literaturas sapienciais judaicas medievais e as fontes que a elas se referem, dentro e fora da mesma tradição. No caso particular da filosofia medieval judaica, isso também permite perceber o momento em que o vocabulário filosófico não estava ainda completamente fixado e diferente expressões foram usadas concomitantemente.

Sob que aspecto a expressão ein sof significa um acréscimo? Ao descrever a série infinita de causa e efeito, no enunciado de Narboni, com ein sof, a ideia da série como tendo existência contínua já está em gérmen. Isso por que a expressão ein sof, composta de duas partículas: ein, que faz a negação; e o termo sof, que deriva da raiz hebraica safá que significa "deixar de existir". ${ }^{82}$ Ein sof, assim, é o que não pode deixar de existir, isto é o que existem constantemente. Evidencia-se aqui outro aspecto da ideia de infinito como existência contínua eterna e sem limite. Essa existência infinita é dupla, pois é tanto a da Primeira Causa (Haiav He-Metziut) enquanto a atividade contínua infinita (ein sof) de gerar a série de causa e efeito, quanto dos seres contingentes entre si, cuja existência é apenas possível (iefshar hámetziut) e que juntos constituem a existência ou o universo infinito (há-metziut). Com relação à série infinita de causa e efeito, Narboni está a afirmar que tal série, por ser formada por seres contingentes, não poderia existir com duração infinita. Por outro lado, para Crescas, a causa primeira é simultânea a todos os efeitos e é assim o fator determinante para a que a série infinita possa continuar a existir. Essa causa primeira, por ser simultânea a cada efeito, é assim imanente à série toda. Os efeitos, porém, por estarem ordenados no tempo, mantêm entre si outra categoria de causalidade, não necessária, mas acidental. Em Crescas, é deste ponto crucial que nasce logicamente, tanto sua tese da criação eterna, quanto seu particular determinismo. Mas também é deste ponto que começa a ser tecida sua prova da existência de Deus, que será citada de maneira elogiosa, por Espinosa, em sua Carta sobre o Infinito, dois séculos e meio depois da publicação de Or Hashem. No outono medieval, entre o final do século XIV e o começo do século XV, a tese de Hasdai Crescas, aponta para uma a concepção de um universo infinito, para além do mundo fechado e finito do aristotelismo recebido da falsafa e que se tornou a concepção dominante entre cristãos latinos e judeus medievas.

\footnotetext{
${ }^{81}$ Emmanuel Lévinas, Totalidade e Infinito (Lisboa: Edições 70, 1980), 175, 272.

82 Sefer Yetzirá, trad. Ariel Kaplan (São Paulo: Ed. Sefer, 1990), 80. Ver também: Salmo 40:15, Jeremias 12:4, Gênesis 18:23.
} 